\title{
A Independência e uma cultura de história no Brasil ${ }^{1}$
}

The Independence of Brazil and a Culture of History

\author{
João Paulo Pimenta, César \\ Augusto Atti, Sheila Virgínia \\ Castro, Nadiesda Dimambro, \\ Beatriz Duarte Lanna, Marina Pupo \\ e Luís Otávio Vieira
} (FFLCH/USP - São Paulo/Brasil) ${ }^{2}$

\section{1}

Versões iniciais desta pesquisa foram apresentadas no Instituto de História da PUC-Chile (junho de 2013), no Instituto de Ciências Sociais da Universidade de Lisboa (julho de 2013), no Fórum da revista Almanack, na Universidade Federal de São Paulo (maio de 2014), e na Universidade Federal do Estado do Rio de Janeiro (outubro de 2014), ocasiões em que seus autores puderam aproveitarse enormemente de criticas e sugestões realizadas por Fernando Purcell, Rafael Sagredo, Ana Maria Stuven, Patricio Bernedo, Felipe Del Solar, Barbara Silva, Javiera Müller, Nuno Gonçalo Monteiro, José Luis Cardoso, Roberta Stumpf, Andréa Slemian, Marcelo Vieira Magalhães, Miguel da Cruz, Wilma Peres Costa, André Roberto Machado, Marcelo de Souza Magalhães, Helenice Rocha, Eunícia Barcelos Fernandes, Cristiani Bereta da Silva e Juçara Barbosa de Mello. Nas duas últimas ocasiões, Rebeca Gontijo, lara Lis Schiavinatto e Ângela de Castro Gomes ofereceram amplas e circunstanciadas resenhas criticas do texto. Sérgio Campos Mattos, Fábio Franzini e Elaine Lourenço se interessaram pelo trabalho desde o inicio, com ele colaborando de diversas formas. E Jaqueline Lourenço e a direção do Colégio Dante Alighieri (São Paulo) viabilizaram etapas importantes de sua realização. A todos eles, nossos profundos agradecimentos.

2

João Paulo Pimenta é professor Livre-Docente no Departamento de História da Universidade de São Paulo (FFLCH/USP), e-mail: jgarrido@usp.br; César Augusto Atti é graduado em História pela Universidade de São Paulo (FFLCH/USP) e professor da rede pública de ensino do Estado de São Paulo, e-mail: cesar.atti@yahoo.com; Sheila Virgínia Castro é graduanda em História pela Universidade de São Paulo (FFLCH/USP), e-mail: svcastro83@gmail.com; Nadiesda Dimambro é graduada em História pela Universidade de São Paulo (FFLCH/USP), e-mail: nanadimambro@gmail.com; Beatriz Duarte Lanna é graduanda em História pela Universidade de São Paulo (FFLCH/USP), e-mail: bduartelanna@gmail. com; Marina Pupo é graduanda em História pela Universidade de São Paulo (FFLCH/USP) e em Direito

\section{Resumo}

0 objetivo deste artigo é propor uma análise preliminar de atitudes e valores que os brasileiros da atualidade nutrem diante de um fato histórico específico - a Independência do Brasil - bem como refletir acerca das relações de tais valores e atitudes com condições acadêmicas de formulação intelectual em torno do fato histórico. A investigação está baseada em livros didáticos, best-sellers, vídeos, filmes e magazines de história, bem como em uma pesquisa de opinião pública. Por fim, 0 artigo discute a noção de "cultura de história", e como a mesma pode eventualmente pautar valores sociais dos brasileiros em relação ao passado.

\section{Abstract}

The aim of this article is to propose a preliminary analysis of attitudes and values that Brazilians have nowadays about a specific historical event the Independence of Brazil - as well as reflecting on the relationship of such values and attitudes towards academic conditions of intellectual formulation around a historical fact. The research is based on textbooks, bestsellers, videos, movies and History magazines as well as on a public opinion pool. Finally, the article discusses the notion of "culture of history", and how it can possibly guide Brazilian social values about the past.

\section{Palavras-chave}

Independência, cultura de história, história pública, ensino de história, historiografia

\section{Keywords}

Independence, culture of history, public history, history teaching, historiography 
pela Pontifícia Universidade Católica (PUC-SP), e-mail: marinapupo@gmail.com; Luís Otávio Vieira é graduando em História pela Universidade de São Paulo (FFLCH/USP) e bolsista da Fundação de Amparo à Pesquisa do Estado de São Paulo (FAPESP), e-mail: luis.otavio.vieira@usp.br

3

DEVOTO, Fernando. Introducción. In (Dir.). Historiadores, ensayistas y gran público: la historiografía argentina, 1990-2010. Buenos Aires: Biblos, 2010, p. 10 (evocando uma ideia de Krzysztof Pomian).
4

Reconhecemos que tal proposta estaria melhor enquadrada com a devida apreciação de outras certamente muito próximas a ela, relativas a "cultura histórica", "cultura política" e "enquadramentos de memória", mas que aqui não puderam ser consideradas a tempo: LE GOFF, Jacques. História. História e memória. Campinas: EDUNICAMP, 1990, p.47-48; GOMES, Ângela de Castro. Cultura Política e cultura histórica no Estado Novo. In: ABREU, Martha; SOIHET, Rachel; GONTIJO, Rebeca (Org.). Cultura Política e leituras do passado: historiografia e ensino de história. Rio de Janeiro: Civilização Brasileira, 2007 p.43-63; e GOMES, Ângela de Castro. Historia, historiografia y cultura politica en Brasil: algunas reflexiones. Ayer v. 2, 2008, p.115-139.

5

MATOS, Sérgio Campos. Consciência histórica e nacionalismo: Portugal, séculos XIX e XX. Lisboa: Horizonte, 2008.

Para o quê, vale a distinção entre operações de memória individual e de memória coletiva estabelecidas por Paul Ricoeur. RICOEUR, Paul. A memória, a história, o esquecimento. Campinas: Editora Unicamp, 2007, parte 1.
1 - Apresentação: cultura de história

A escrita da História não é e nunca foi monopólio dos historiadores. ${ }^{3}$ De muitas maneiras, ela sempre foi compartilhada entre profissionais da matéria e uma grande variedade de agentes sociais de formação e atuação igualmente variados, a imporem um processo permanente de disputa e negociação. Atualmente, poder-se-ia falar em educadores, escritores, cineastas, artistas plásticos, jornalistas, juristas, políticos profissionais, publicitários e teólogos, além de outras pessoas em geral, a representarem, reproduzirem e eventualmente criarem conhecimentos históricos em uma interação mais ou menos harmônica, mais ou menos conflitiva - mas sempre dinâmica e contraditória - com historiadores acadêmicos e demais cientistas sociais. Essa interação é fenômeno relevante. No entanto, e a despeito de uma clara tendência mundial de proliferação de estudos acerca do papel público desempenhado pelos historiadores, assim como de um crescente envolvimento dos mesmos em espaços a eles oferecidos pela sociedade, ainda parece muito escassa a reflexão em torno de alguns pressupostos dessa relação entre historiadores e seu meio social, especialmente à luz da constatação de que os saberes formulados por tais profissionais estão submetidos não apenas ao seu meio social em geral, mas também a um conjunto de saberes especificos presentes, veiculados e reproduzidos por esse meio.

Tal observação, aparentemente óbvia, ganha pertinência na medida em que seu foco se ajusta, mais precisamente, em dois problemas convergentes: 1) o da possibilidade de se extrair, dessa relação entre profissionais e não profissionais da História, uma caracterização mais ampla da sociedade onde ela ocorre; 2) o do ponto de partida do estudo acadêmico/profissional de uma matéria específica como parcialmente determinado pela alocação e manipulação dessa mesma matéria em uma sociedade, por ação daqueles variados agentes acima mencionados. Este artigo enfrenta tais questões a partir de uma observação circunscrita a um único tema histórico e à realidade brasileira do presente, mas considerando que muitas das feições do que aqui se observa não são peculiares ao Brasil, tipificando também, em parte, outras realidades. Como os brasileiros veem a Independência do Brasi? As respostas apresentadas, naturalmente limitadas pelo escopo da pesquisa, pretendem esboçar uma caracterização de um aspecto da sociedade brasileira da atualidade: como os brasileiros se relacionam com sua história. Em seu esteio, e como uma sorte de efeito colateral do objetivo principal, tais respostas pretendem também retomar a discussão em torno de como $a$ Independência é vista, no Brasil, por seus historiadores. 0 que resulta, então, em um estudo ao mesmo tempo histórico e historiográfico.

Em linhas gerais, esta é uma investigação sobre um fenômeno que poderiamos chamar de cultura de história. Entende-se tal fenômeno como um conjunto de atitudes e valores que se expressam em noções, concepções, representações, conceptualizações, interdições e outras posturas, de uma determinada sociedade em relação a um passado que pode ser considerado como coletivo. Uma cultura de história, portanto, não se confunde com consciência histórica, antes, engloba-a e a expande ${ }^{4}$. Consciência histórica pode ser definida como aquela que significativo grupo de sujeitos em sociedade tem de compartilharem um passado, o que enseja e condiciona formas de se pensar o presente e de projetar futuros coletivos; $;{ }^{5}$ a cultura de história, por outro lado, engloba também os silêncios e as recusas desses sujeitos em relação ao passado, seja por meio de atitudes deliberadas ou não, ${ }^{6}$ resultantes ou não de vontades coletivas. 
7

Nos anos de 1950, José Honório Rodrigues concebia uma nociva crise na sociedade brasileira, relativa a um "declinio de consciência histórica", na qual o passado se confinaria a cultos nostálgicos, e diante da qual o historiador ele, em particular - deveria elaborar estratégias de atuação. RODRIGUES, José Honório. A pesquisa histórica no Brasil: sua evolução e problemas atuais. Rio de Janeiro: Imprensa Nacional/ INL, 1952. Citado em: FREIXO, André de Lemos. Ousadia e redenção: o Instituto de Pesquisa Histórica de José Honório Rodrigues. História da historiografia, n.11, abril de 2013, p.155.

8

Nas palavras de um historiador dedicado ao estudo da identidade nacional portuguesa, "esse tipo de caracterizações genéricas, de lugarescomuns sem fundamento, ou que constituem generalizações abusivas a partir de fatos pontuais, são, no entanto, importantes, porque assinalam diferenças que se julga existirem entre as nações. São um testemunho da existência destas, pois todos os grupos nacionais possuem estereótipos sobre si próprios e sobre os outros, que são inerentes à própria construção de uma identidade". SOBRAL, José Manuel. Portugal, portugueses: uma identidade nacional. Lisboa: Fundação Francisco Manuel dos Santos, 2012, p.17. Também CARDOSO, Patrícia da Silva. D. João VI, um imaginário revisitado. In: OLIVEIRA, Paulo da Motta (org.). Travessias: D. João VI e o mundo Iusófono. Cotia: Ateliê, 2013, p.38.

9

RUSEN, Jorn. História Viva. Teoria da História III: formas e funções do conhecimento histórico. Brasilia: Ed. da UNB, 2007.

10

Escapa ao escopo desta pesquisa, por exemplo, uma perquirição mais ampla a respeito de como a sociedade brasileira vê noções advindas de um pensamento que poderiamos chamar de "histórico", como ideias de temporalidade (futuro, passado, presente, instante, progresso, desenvolvimento, etc.). Tal empreendimento, de momento apenas sugerido pelo confinamento dos objetivos aqui expostos a uma análise das formas sociais de relacionamento com um passado coletivo ("história"), pareceria estar em sintonia com a proposta de Rüsen. Para uma proposta acerca de "cultura histórica" socialmente mais restritiva do que a nossa, aplicada ao mundo medieval, vide a importante obra de Guenée. GUENÉE, Bernard. Histoire et culture historique dans l'Occident medieval. Paris: Aubier-

Montaigne, 1980, em especial o cap.7, "La culture historique".

11

NORA, Pierre. Entre memoria e historia. La problemática de los lugares. In: Pierre Nora en Les lieux de mémoire. Santiago: LOM/Trilce, 2009, p.5-47. Também DIEHL, Antonio Astor. Cultura historiográfica: memória, identidade e representação. Bauru: Edusc, 2002.
0 caso brasileiro oferece subsídio interessante a essa diferenciação de abrangência entre consciência histórica e cultura de história. Não é assiduamente frequente em nossa sociedade uma autoimagem dos brasileiros como "povo sem memória", em um jogo de identidades e alteridades que, ao mesmo tempo em que distingue aqueles indivíduos que supostamente valorizam o passado e os saberes em torno dele, acaba por incluí-los em uma mesma coletividade a qual se acusa de estar enferma da doença do esquecimento e da ignorância? Para efeitos de caracterização de uma cultura de história no Brasil, essa autoimagem é incapaz de modelar teoricamente uma análise. Afinal, se houver algo nesses "brasileiros" (quais, quantos, quando, onde, como, por quê?) que realmente permita caracterizá-los como pouco ou nada afeitos ao conhecimento do passado de sua sociedade, sua devida compreensão deve ir além da noção de consciência histórica. Como veremos adiante, esse é um estereótipo (mais um) em torno do Brasil e dos brasileiros, e que vê sua essencialização de um suposto caráter nacional cair por terra diante da consideração de que quaisquer atitudes e valores sociais - mesmo os negativos - em relação ao passado são fenômenos em si, e que seria praticamente impossivel nos defrontarmos com sujeitos que, no Brasil, ignorassem ou desprezassem o conhecimento do passado em termos absolutos. Todo brasileiro pensa algo sobre a história, mesmo que não a valorize ou com ela não se importe. Mesmo assim, os estereótipos nacionais podem ser considerados dados de uma realidade, de uma autoimagem dos brasileiros. ${ }^{8}$ Tratá-los como tal sugere, então, a utilização da noção de cultura de história.

Jorn Rüsen concebe a expressão cultura histórica em referência a algo distinto: as formas pelas quais uma sociedade racionaliza pressupostos (também eles racionais) advindos do pensamento histórico; ou seja, uma interação entre pensamento histórico e coletividades humanas na qual estas se aproveitam, em termos práticos, do que aquele é capaz de sistematizar. ${ }^{9}$ Nas páginas que se seguem, em nenhum momento pretendeu-se expropriar a expressão de Rüsen, tampouco revisar sua proposta analítica (é possível mesmo que seu exame mais detido indicasse possibilidades de diálogo ou até de convergências aqui não devidamente exploradas $^{10}$ ). Ocorre que o pensamento é cativo da linguagem, e não se dispõe de melhor expressão a indicar o que aqui se pretende mostrar que uma a ela semelhante: cultura de história. Para efeitos de elucidação do problema, poderiamos transliterar a proposta de Rüsen em termos de uma cultura de pensamento histórico e, com isso, evocar as elaborações de Pierre Nora, a ela anteriores, em torno de uma cultura historiográfica: isto é, a consciência coletiva que uma sociedade tem (a francesa, talvez; a brasileira só muito residualmente) não apenas de uma história compartilhada, mas também dos meios que ela -a sociedade -dispõe para reelaborar tal história por dispositivos de memória. ${ }^{11}$ Nora se interessa pelas condições de realização coletiva de uma crítica da presença da história e da memória que, para Rusen, não deixaria de indicar um potencial racionalizador advindo do próprio pensamento histórico. Tal convergência reforça aspectos centrais da cultura de história aqui tratada, mas não a esgota plenamente, sobretudo - repitamos -no tocante aos seus silêncios e interdições, que também devem ser levados em conta.

Cultura de história, aqui, não se confunde com costume, ao menos tal como este é pensado por E. P. Thompson: fenômeno advindo da práxis e situado na interface desta com a lei, portador de expectativas coletivas e 
THOMPSON, Edward Palmer. Costumes em comum: estudos sobre a cultura popular tradicional. São Paulo: Companhia das Letras, 1998, em especial p.13-15 e p.86. Há que se notar que 0 autor evita a manipulação de definições claras e aprioristicas, preferindo a construção das mesmas com base no desenvolvimento de suas pesquisas empíricas.

13

0 que não significa que os atributos de uma cultura histórica não possam ser apropriados e manipulados politicamente, ou constituírem-se em subsidios para projetos de futuro; a ausência se refere a uma distribuição e tendencial confinamento por classes de tais atributos.

14

RUSEN, Jorn. Tradition: a principle of historical sense-generation and its logic and effect in historical culture. History and Theory, Theme Issue 51, dez/2012. Também FREIXO, André de Lemos. Ousadia e redenção. Op. Cit., p.157.

15

LYRA, Maria de Lourdes Vianna. Memória da Independência: marcos e representações simbólicas. Revista Brasileira de História, n.29, 1995, p.173-206; OLIVEIRA, Cecília Helena de Salles. 0 Espetáculo do Ipiranga: reflexões preliminares sobre o imaginário da Independência. Anais do Museu Paulista, São Paulo, v.3, 1995, p.195-208; OLIVEIRA, Cecília Helena de Salles e MATTOS, Cláudia Valladão (org.). O Brado do Ipiranga. São Paulo: EDUSP, 1999; WEHLING, Arno. Estado, História, Memória. Varnhagen e a construção da identidade nacional. Rio de Janeiro: Nova Fronteira/UNIRIO, 1999; ENDERS, Armelle. Os vultos da nação: fábrica de heróis e formação dos brasileiros. Rio de Janeiro: Editora FGV, 2014.

16

Em referência, novamente, a NORA, Pierre. Entre memoria e historia. Op. Cit.

17

Um dado contundente: segundo a inovadora pesquisa realizada pela educadora Ana Teresa da Purificação, de um grupo de 97 crianças entre 9 e 13 anos e que jamais tinham sido introduzidas formalmente ao tema da Independência do Brasil, 82 foram capazes de representá-la de alguma maneira (desenhos, frases), geralmente em forte conexão com representações sociais mais amplas (D. Pedro, o Grito, o Sete de Setembro, a bandeira nacional, uma luta dicotômica entre bem e mal, etc.). PURIFICAÇÃO, Ana Teresa da. (Re)criando interpretações sobre a Independência do Brasil: um estudo das mediações entre memória e história nos livros didáticos. 2002. Dissertação (Mestrado em História). Faculdade de Filosofia, Letras e Ciências Humanas, Universidade de São Paulo, São Paulo, 2002.

18

Exemplo interessante é o livro de Luís Fernando Cerri, com ênfase em uma consciência histórica focada na história da ditadura brasileira de 1964 a 1985, e com aproximações com outros paises do cone sul. Cfr. CERRI, Luís Fernando. Ensino de história e consciência histórica: implicações didáticas de uma discussão contemporânea. Rio de Janeiro: Editora FGV, 2011. potencial realizador de reivindicações dinamizadoras de conflitos em torno da divisão de classes de uma sociedade. ${ }^{12}$ Como se verá a seguir, embora a cultura de história aqui observada esteja, evidentemente, condicionada pelas estruturas sociais presentes na própria sociedade à qual se refere, ela não parece caracterizada por uma distribuição classista de seus principais atributos, tampouco por uma carga classista de expectativas políticas potencialmente irruptivas em seu contexto ${ }^{13}$. Cultura de história também não se confunde perfeitamente com tradição, segundo a tripla distinção proposta, mais uma vez, por Rüsen: seja como afirmação passiva, funcional e valorativa das formas já estabelecidas de vida social; como manancial de conteúdos aparentemente esquecidos, inconscientes, mas latentes em uma coletividade; seja, ainda, como ponto de partida para a continuidade crítica de um discurso tornado reflexivo, logo histórico ${ }^{14}$. Afinal, e embora uma cultura de história possa se conectar em parte com tais "tradições", nenhuma delas parece englobar devidamente as interdições e os silêncios acima referidos, e aqui perscrutados. Para todos os efeitos, no entanto, trata-se de um tipo de cultura, isto é, de um sistema social dotado de forte estabilidade, mas não completamente inercial; pautado por alguns consensos a organizarem a maioria de seus dissensos; e submetido a uma dinâmica transformadora tendencialmente lenta, embora suscetivel a alterações de monta a partir de fatos pontuais e aparentemente isolados.

A Independência do Brasil, ocorrida na primeira metade do século XIX, é tema especialmente propício para a caracterização inicial de uma cultura de história no Brasil. Não é o único possível, mas sem dúvida se presta especialmente bem a tal tarefa. Visto como um conjunto de tópicos que, a depender do enfoque, pode incluir a história da América portuguesa nos últimos anos do século XVIII, a crise da monarquia bragantina a partir de 1807, a separação política entre Portugal e Brasil e a formação inicial deste como Estado e nação, a Independência é tema fundador, desde sempre presente em processos de formação escolar básicos, na mídia, nas artes, na política, na opinião pública, nos espaços públicos, no senso-comum e na memória nacional. ${ }^{15}$ Não há cidade no Brasil que não tenha seus lugares de memória ${ }^{16}$ ligados à Independência, não há processo escolar formal que a ignore, não há feriados nacionais mais importantes em termos de evocação pública e midiática de conteúdos do que os dela derivados. Em certa medida, a Independência "paira" por sobre a sociedade brasileira e com ela interage, o que faz com que praticamente todo e qualquer brasileiro, a partir de uma certa idade, pense alguma coisa a seu respeito. ${ }^{17}$

A cultura de história brasileira, que não se esgota na Independência, com ela se confunde.

Além disso, para efeitos da realização desta pesquisa, seus autores estão, por dever de ofício, mais familiarizados historiograficamente com o tema do que com outros que, poderiam, igualmente, se constituir em pontos de partida válidos. ${ }^{18}$ Com isso, não se quer dizer que este seja um estudo acerca de práticas acadêmicas em relação à História per se, e que sem dúvida também são parte constitutiva dessa cultura de história no Brasil e alhures ${ }^{19}$ (aliás, como se verá, aqui estas surgirão a reboque das práticas não acadêmicas); apenas que o ponto de vista adotado pela pesquisa, e a partir dos quais seus autores se reconhecem, é acadêmico, o que os permite explorar determinados potenciais do tema.

A Independência mostra que há uma dimensão nacional na cultura de história, a impor significativas variações morfológicas e temáticas de 
CHARLE, Christophe. Homo historicus: réflexions sur l'histoire, les historiens et les sciences sociales. Paris: Armand Colin, 2013.

20

SOBRAL, José Manuel. Op. Cit.; SMITH, Anthony D. Myths and Memories of the Nation. New York: Oxford University Press, 1999; ANDERSON, Benedict. Nação e consciência nacional. São Paulo: Ática, 1989; HOBSBAWM, Eric J. Nações e nacionalismo desde 1780: programa, mito, realidade. Rio de Janeiro: Paz e Terra, 1990; JANCSÓ, István. Brasil e brasileiros: notas sobre modelagem de significados politicos na crise do Antigo Regime português na América. Estudos Avançados, v.22, p.257-274, 2008. Mesmo suportes midiáticos eminentemente transnacionais, ou até mesmo supranacionais, típicos do mundo digital, não apenas se mostram incapazes de romper com a dimensão nacional do fenômeno, como em muitos casos até contribuem para reforçá-la.

21

Embora, como logo se verá, a ela tenha-se procurado dar, em parte, um perfil nacional brasileiro.

Os critérios exatos dessa sondagem, bem como os detalhes relativos às outras fontes utilizadas, encontram-se descritos nos próximos itens. país a país, embora - repita-se - deva-se esperar também feições comuns entre diferentes culturas históricas. Ao mesmo tempo, há uma tendência à unificação dessas formas e temas no interior de um mesmo pais, resultado da vigência de memórias e identidades, bem como de estruturas institucionais de tipo nacional, tais como sistemas políticos, escolares e universitários, também eles prenhes de conteúdos referentes a temas históricos comparáveis em importância, em cada contexto respectivo, ao da Independência no Brasil. Como bem tem mostrado a historiografia da questão nacional, o passado coletivo é pretexto especialmente forte para a constituição e reprodução de identidades nacionais. ${ }^{20}$ É por isso que aqui cultura de história é tratada no singular, pressupondo, contudo, uma homogeneidade apenas relativa e parcial do fenômeno.

Também há dimensões regionais nessa cultura de história, com variações a depender dos diferentes modos de contar, evocar e silenciar conteúdos da história coletiva característicos de cada quadrante espacial dessa unidade nacional, sem, contudo, romper com a unidade que a engloba. As limitações do presente estudo quanto a esse ponto são explícitas, ao mesmo tempo em que contribuem para um desenho das feições mais gerais do fenômeno. Afinal, uma parte dos materiais empíricos aqui utilizados (mais precisamente a sondagem de opinião, apresentada no item 3) refere-se primordialmente a São Paulo e sua capital ${ }^{21}$ outros, porém, são de alcance claramente nacional, o que permite o estabelecimento de mediações entre as esferas micro e macro históricas constitutivas do fenômeno. No entanto, fica a advertência: é possivel que a expansão dessa base empírica para materiais regionalmente mais circunscritos a outros Estados do Brasil como Pará, Maranhão, Pernambuco, Bahia, Minas Gerais, Rio de Janeiro ou Rio Grande do Sul, por exemplo, ou mesmo a cidades singularmente marcadas pela história da Independência, como Cametá, Cachoeira e Goiana, nos mostrasse variações capazes de redefinir o fenômeno geral. Não foi a Independência do Brasil um processo histórico cheio de nuances regionais e locais capazes de legar à posteridade um leque de memórias ainda operativas na sociedade brasileira atual? Porém, a história da Independência na cultura brasileira de história precisa de algum ponto de partida, mesmo que limitado.

Finalmente, há que se explicitar que há uma dimensão histórica nessa cultura de história, o que implica a concepção de um fenômeno que, embora marcado por considerável estabilidade e regularidade, é dinâmico. Isso quer dizer que as conclusões daqui extraídas forçosamente trazem uma limitação conjuntural, podendo ser revistas ou mesmo invalidadas no futuro, não apenas em função da inescapável (e óbvia) condição proteica do conhecimento histórico; mas também porque o sistema que constitui esse fenômeno é composto de uma grande quantidade de fenômenos menores que podem, efetivamente, modificar a essência do conjunto - novas políticas educacionais, um seriado de televisão de grande audiência, um best-seller de divulgação histórica, uma efeméride de impacto, etc.

2 - Como apreender uma cultura de história? Fontes e questões centrais Como descrever e analisar um fenômeno histórico com tais caracteristicas? Aqui, definiu-se estrategicamente uma fonte central a organizar as demais: uma sondagem de opinião aplicada presencialmente nas ruas da cidade de São Paulo por meio de um questionário e que incidiu sobre uma amostragem de 311 pessoas de diversa formação escolar, faixa etária, características sócio-econômico-culturais e procedência regional. ${ }^{22}$ Embora se consti- 
Sendo a população total 190.732 .694 , de acordo com o Censo Demográfico 2010 do IBGE. Disponivel em ibge.gov.br/home/estatistica/ populacao/censo2010/default.shtm. Acesso em 01/04/2014.

24

A realização da mesma, assim como a interpretação de seus dados, teve em conta premissas metodológicas gerais estabelecidas por Patrick Champagne. CHAMPAGNE, Patrick. Formar a opinião: o novo jogo politico. Petrópolis: Vozes, 1998; ZALLER, John R. The Nature and Origins of Mass Opnion. Cambridge: Cambridge University Press, 1992; WILHOIT, Cleveland e WEAVER, David H. Neswroom Guide to Polls \& Surveys. Bloomington and Indianapolis: Indiana University Press, 1990; e MONZÓN ARRIBAS, Cándido. La opinión pública: teorias, conceptos y métodos. Madri: Tecnos, 1987.

25

COSSE, Isabela e MARKARIAN, Vania. Memorias de la historia: una aproximación al estudio de la consciencia histórica nacional. Montevidéu: Trilce, 1994; PAIS, José Machado. Consciência histórica e identidade: os jovens portugueses num contexto europeu. Oeiras: Celta/Secretaria de Estado da Juventude, 1999. Este último inclui vários dos resultados obtidos pelo inquérito geral europeu realizado com jovens e professores de História de 26 paises do continente, mais Israel, "Israel Árabe" e "Palestina".

26

Seria importante considerar, ainda, atitudes de pessoas em relação a lugares de memória especificamente ligados à Independência do Brasil dentro das cidades, existentes, aliás, em praticamente todo e qualquer centro urbano do país. No caso de São Paulo, tal desafio pode encontrar estimulante ponto de partida em duas pesquisas: OLIVEIRA, Cecilia Helena de Salles. Museu Paulista: espaço de evocação do passado e reflexão sobre a história. Anais do Museu Paulista, São Paulo, Nova Série v.10/11, 2002/2003, p.105126; e ALMEIDA, Adriana Mortara. Os visitantes do Museu Paulista: um estudo comparativo com os visitantes da Pinacoteca do Estado e do Museu de Zoologia. Anais do Museu Paulista, São Paulo, Nova Série, v.12, 2004, p.269-306.

27

0 PNLD tem como objetivo central "subsidiar o trabalho pedagógico dos professores por meio da distribuição de coleções de livros didáticos aos alunos da educação básica. Após a avaliação das obras, o Ministério da Educação (MEC) publica o Guia de Livros Didáticos com resenhas das coleções consideradas aprovadas. 0 guia é encaminhado às escolas, que escolhem, entre os títulos disponíveis, aqueles que melhor atendem ao seu projeto político pedagógico" (portal.mec.gov.br) index.php? ltemid=668id=12391 option =com_ contentview=article). $A$ avaliação e seleção dos títulos aprovados pelo programa coube à Secretaria de Educação Básica (SEB) do Ministério da Educação, sendo a equipe avaliadora formada por professores de várias universidades públicas. Guia de livros didáticos: PNLD 2012: História. Brasília: Ministério da Educação, Secretaria de Educação Básica, 2011. tua em um universo numérico bastante pequeno diante da totalidade da população brasileira a partir de 15 anos (144.814.538 indivíduos, de acordo com o censo do IBGE de $2010^{23}$ ), métodos específicos que subsidiaram a concepção e aplicação dessa sondagem permitiram o alcance de resultados relevantes, como se verá adiante. ${ }^{24} \mathrm{~A}$ utilização de tal abordagem em estudos de História é pouco frequente, mas não inédita. Deve-se aqui mencionar dois estudos importantes e parcialmente convergentes com os propósitos desta pesquisa: o de Isabela Cosse e Vania Markarian sobre a consciência histórica nacional no Uruguai, publicado em 1994; e o coordenado por José Machado Pais, sobre a consciência histórica dos jovens portugueses nos contextos europeu e israelense/palestino, de $1999 .{ }^{25}$ Ambos são excelentes demonstrações dos potenciais oferecidos por esse tipo de abordagem e forneceram norte e estímulo a esta pesquisa, mas dela diferem em três pontos fundamentais: sua circunscrição nacional/continental; ${ }^{26}$ os contextos históricos de sua elaboração; e a abordagem realizada em torno de temas de história em geral, pressupondo que os entrevistados possuiriam posições ativas em torno do passado. Assim, abordam formas de consciência histórica, mas não a ampliam em direção a uma cultura de história.

A sondagem de opinião é aqui central, mas não exclusiva, tendo sido seus resultados cotejados com os extraídos da análise de um conjunto de fontes complementares. Em primeiro lugar, livros didáticos de Ensino Médio, utilizados por professores e alunos em 2013, nos quais foram buscados especificamente tópicos relativos à Independência do Brasil. Esse conjunto de fontes perfaz 19 títulos, que foram avaliados e aprovados pelo Governo Federal brasileiro no Programa Nacional do Livro Didático em 2012, cujos cerca de 7 milhões e 500 mil exemplares foram distribuídos a algo como 18 mil escolas públicas de todo o país, além de serem utilizados também em escolas privadas; ${ }^{27}$ completaram a análise dados obtidos por uma estudiosa de livros didáticos de Ensino Fundamental, também recomendados pelo governo em 1998, e que analisou 12 títulos. $^{28}$ Em segundo lugar, vídeos disponíveis no YouTube portadores de conteúdos relativos à Independência. Aqui, deparou-se com material muito variado, distribuido em 107 vídeos que perfazem um riquíssimo conjunto, dada sua grande diversidade morfológica e de conteúdo (seriados educativos, entrevistas, programas jornalísticos, propagandas de partidos políticos ou de outras associações, trailers de filmes, programas voltados para público jovem, produções independentes, etc.) e também pelas possibilidades de mensuração parcial de seu alcance, via o número de visualizações indicadas pelo sítio, e de análise dos respectivos "comentários", também lá disponiveis. Em terceiro lugar, obras televisivas e cinematográficas relacionadas com a Independência do Brasil. Aqui, foram analisadas três séries televisivas e cinco longas-metragens, todos também disponíveis no YouTube com os mesmos dados complementares acima apontados. Em quarto lugar, livros de divulgação acadêmica ou jornalística, romances históricos, comics, livros paradidáticos e outras obras de difícil definição, a possuírem em comum abordagens da história da Independência apresentadas em linguagem não acadêmica destinadas a um público potencialmente amplo e diversificado, não restrito, portanto, a estudantes e professores de História ${ }^{29}$. Em meio a esse conjunto, foram selecionados 19 livros. Finalmente, em quinto lugar, foram analisados artigos sobre a Independência publicados em cinco magazines de História vendidos em bancas de jornal e livrarias, e que visam divulgar saberes especializados para um público mais além do frequentador de cursos universitários de História. 
Tal tipo de fonte é o que melhor permite uma análise de mais largo escopo temporal do que o aqui contemplado. Uma excelente reunião preliminar de material encontra-se em CALMON, Pedro. História do Brasil na poesia do povo. Nova edição aumentada. Rio de Janeiro: Bloch, 1973. Para noções, concepções e representações da Independência na literatura e na dramaturgia portuguesa, vários apontamentos em: OLIVEIRA, Paulo da Motta. (org.) Op. Cit.

30

Muitas já vêm sendo analisadas separadamente, de acordo com uma tendência apontada acima. Para os livros didáticos, a produção é imensa, e inclui trabalhos importantes como os de BITTENCOURT, Circe Fernandes. Livro didático e conhecimento histórico: uma história do saber escolar. 1993. Tese. (Doutorado em História Social). Faculdade de Filosofia, Letras e Ciências Humanas, Universidade de São Paulo, São Paulo, 1993; MUNAKATA, Kazumi. Produzindo livros didáticos e paradidáticos. Tese. 1997. (Doutorado em História e Filosofia da Educação). Pontifícia Universidade Católica de São Paulo, São Paulo, 1997; DIEHL, Astor Antônio (org.). O livro didático e o currículo de história em transição. Passo Fundo: EDIUPF, 1999; e CARDOSO, Oldimar Pontes. A didática da história e o slogan da formação de cidadãos. 2007. Tese. (Doutorado em Educação). Faculdade de Educação, Universidade de São Paulo, São Paulo, 2007. Sobre cinema e história, dentre outros: FONSECA, Vitória Azevedo da. História imaginada no cinema: análise de Carlota Joaquina, princesa do Brazil e Independência ou morte. 2002. Dissertação (Mestrado em História Cultural), Universidade Estadual de Campinas, Campinas, 2002.

31

Esse é o perfil mostrado pelo censo do IBGE de 2010, com algumas poucas exceções; no caso da amostragem, a única importante se observa com a faixa etária de 25 a 29 anos (14\%), mais numerosa do que a anterior, entre 20 e 24 anos (8\%), sendo que a porcentagem da população brasileira em tais faixas etárias é praticamente a mesma (respectivamente 8\% e 9\%). De resto, foi possivel estabelecer, nesse quesito, uma satisfatória correlação com o perfil brasileiro: a amostragem abordou indivíduos a partir de 15 anos, sendo que dos 14 grupos de cinco anos obtidos (o último corresponde a 80 anos ou mais), quatro apresentaram perfeita correspondência percentual com os dados nacionais, oito uma diferença de no máximo 2 \%, e apenas dois, forte discrepância.

32

Para se atingir perfis ocupacionais desejados, algumas entrevistas foram realizadas na região do Grande $A B C$ e no interior do estado de São Paulo.

33

Dados do último Censo do IBGE (2010), disponivel em censo2010.ibge.gov.br/amostra/. Acesso em 01/04/2014.

34

0 censo do IBGE de 2010 indicou a porcentagem de 7,6\% para desocupados considerando o total da população maior de 10 anos. Para o estado
Bem se vê que tais fontes complementares extrapolam o âmbito espacial parcialmente circunscrito da sondagem de opinião, além de permitirem a consideração de uma grande pluralidade de vozes de agentes sociais - inclusive, mas não preferencialmente, os historiadores acadêmicos - responsáveis pela inexistência de um monopólio profissional na reprodução, divulgação e eventual produção de conhecimentos acerca da Independência do Brasil. A exemplo dos procedimentos adotados para a realização da sondagem de opinião, também a utilização de tais fontes partiu de uma amostragem, já que nenhum de seus conjuntos corresponde à totalidade de materiais disponiveis. No entanto, acredita-se que a somatória dessas amostragens seja satisfatória para a persecução dos objetivos aqui propostos.

Como tratar metodologicamente fontes tão diferentes entre si, e como fazê-las convergirem para um mesmo fim? Os conteúdos extraídos da sondagem de opinião merecem tratamento algo peculiar, já que, tendo permanecido inéditos até o momento, não podem ser considerados como elementos capazes de agir naquela mesma realidade que os informou; só podem ser vistos como tradução (indireta, matizada) de uma realidade por eles denunciada. Já as demais fontes são consideradas de ambos os modos: como instrumentos de reconfiguração da realidade, em termos de potenciais formadoras de opinião dos brasileiros acerca da Independência, mas também como sintomáticas de um estado de espírito dos brasileiros em torno do tema. Portadoras de indícios de uma cultura de história que elas criam e recriam, e protagonistas ativos dessa mesma cultura. ${ }^{30} 0$ que não quer dizer, de modo algum, que a todos os suportes materiais aqui considerados como fontes primárias possa ser atribuido um caráter de inovação em seus tratamentos dos conteúdos relativos à Independência do Brasil (se assim o fosse, os historiadores profissionais da Independência teriam muitos motivos para comemorar o fato de que os demais agentes sociais não apenas estariam dispostos a ouvi-los, como aptos a compreendê-los. E se assim o fosse, estariamos frente a uma cultura histórica muito mais dinâmica e instável do que ela parece ser).

Para aferir até que ponto um livro, uma revista, um filme ou um vídeo contribuem mais para a criação ou para a recriação (pois não há aqui, estrito senso, simples reprodução) de conteúdos, a metodologia adotada abordou tais suportes materiais por meio de cinco perguntas básicas. Seu tratamento da Independência tende a uma História: 1) Factual e/ou biográfica, ou a uma história processual? 2) Que respeita historicidades e ordenamentos cronológicos e temporais, ou que tende a dar pouca importância a tais elementos (neste caso, de que modos o faz)? 3) Centrada em uma única região (qual?), ou em várias ao mesmo tempo e inclusive a outras partes do mundo da época (quais)? 4) Que dialoga (de que modos?) com a produção acadêmica (qual, de quando?) ou que busca outros referenciais no universo não especializado? 5) De ênfase anedótica, laudatória, sóbria, positiva ou negativa? As respostas a tais perguntas, nem sempre bem claras e definidas, foram buscadas a partir também de substratos metodológicos específicos para cada tipo de fonte, e chegaram a envolver parcialmente também a sondagem de opinião.

\section{3 - A sondagem de opinião. A Independência nas ruas.}

A sondagem de opinião partiu da aplicação de um questionário que mesclou respostas dirigidas e objetivas com respostas abertas e subjetivas, sendo dividido em três partes correspondentes a três perfis a serem extraídos 
de São Paulo a porcentagem é também de 7,6\%. Disponivel em: censo2010.ibge.gov.br/amostra/. Acesso em 01/04/2014.

35

Há aqui algumas discrepâncias em relação as categorias do IBGE que devem ser explicitadas: no que se refere aos critérios de renda estão ausentes do questionário "mais de 2 a 3 salários mínimos"; além disto a renda calculada pelo questionário tem como base a unidade familiar enquanto os dados do IBGE aqui contrastados referem-se à renda de indivíduos.

36

Dos 161.981.299 individuos totais "a partir de 10 anos", subtraiu-se 17.166.761 indivíduos entre 10 e 14 anos, de modo a limitar a estatística nacional aos jovens contemplados pela amostragem. Uma distorção, contudo, permanece na cifra dos indivíduos "sem instrução e fundamental completo" da tabela 1.5.4., pois crianças entre 10 e 14 anos podem perfeitamente ser "sem instrução", embora o sejam em pequena minoria "fundamental completo"; para todos os efeitos, as porcentagens das demais rubricas da mesma tabela foram assim corrigidas, já que crianças de 14 anos estarão necessariamente ausentes da rubrica seguinte, "médio completo" (tabelas 1.5 .4 e 1.12 , respectivamente).

Nos dados do IBGE, a maioria da população (59\%) encontra-se na rubrica "não frequentavam, mas já frequentaram". Dentre os que "frequentavam", 78\% o faziam em estabelecimentos públicos, e $22 \%$ em privados; na amostragem, esses percentuais, que incidem sobre frequência em curso/já realizada, foram, respectivamente, $63 \%$ e $27 \%$, sendo que $11 \%$ se enquadravam em ambos.

38

Também nessa segunda parte, o questionário se afastou progressivamente da possibilidade de estabelecimento de equivalências estatísticas com a totalidade da população brasileira. Isso se deu por um motivo principal: o censo do IBGE não chega ao grau de detalhamento dos dados aqui obtidos (seus objetivos e natureza são outros) e, embora existam sondagens de opinião focadas em perfis culturais do brasileiro (como a edição de 2011 de Retratos da leitura no Brasil, do Instituto Pró-Livro, aqui utilizada como se verá mais adiante), a busca por tais equivalências implicaria o sério risco de um engessamento na obtenção de dados qualitativos. Tendo em vista os objetivos centrais dessa pesquisa - esboçar a caracterização de uma cultura de história no Brasil por meio da Independência, assim como refletir em torno de implicações do tratamento acadêmico do tema a partir de sua inserção nessa mesma cultura - 0 estabelecimento preliminar completo do perfil dos entrevistados não garantiria a validade do materia a ser extraido e analisado. Trata-se justamente do contrário: submeter os resultados finais da pesquisa aos parâmetros dados pelas condições de sua própria realização.

39

Há pelo menos dois exemplos de como rankings se fazem presentes no pensar a História nesse escopo. Um primeiro, de grande participação popular, é o programa de tevê 0 maior brasileiro de todos os tempos, exibido entre 11/07 e do entrevistado: um sócio-econômico-escolar, um cultural, e um relativo à sua relação com a História, em especial a da Independência.

A obtenção do primeiro perfil se fez segundo gênero, faixa etária (em grupos de cinco anos a partir de 15 anos de idade), local de nascimento (segundo regiões do Brasil e cidade), ocupação profissional, renda familiar (em valores ou quantidade de salários mínimos, isto é, $R \$ 620,00$ ) e instrução formal (por níveis, e se realizada em escolas públicas e/ou privadas, cidade e instituição). Com isso, buscou-se aproximar o universo da amostragem - 311 indivíduos - do perfil geral do pais; quando isso não foi possivel, a aproximação se deu com o Estado e com a cidade de São Paulo.

No quesito gênero, foram entrevistadas 52\% de mulheres e $48 \%$ de homens (um dos entrevistados não quis declarar seu gênero), estabelecendo-se uma perfeita correlação de porcentagem com o mostrado pelo censo populacional do IBGE de 2010, seja em termos nacionais ou estaduais de São Paulo. Já a constituição da faixa etária dos entrevistados buscou um modelo de "pirâmide", isto é, com um número de mais jovens sempre mais elevado do que o de mais idosos. ${ }^{31}$ No entanto, aqui a amostragem privilegiou mais jovens entre 15 e 19 anos (21\%) do que a realidade populacional brasileira (8\%), e mais adultos entre 25 e 29 anos.

No tocante ao local de nascimento, a amostragem não pôde se valer de dados do IBGE. Desse modo, buscou-se uma aproximação estatística com a cidade de São Paulo, local onde 97\% das entrevistas foram realizadas. ${ }^{32}$ Os nascidos na região sudeste perfizeram $73 \%$ das abordagens, sendo 67\% naturais do estado de São Paulo (dados do IBGE mostram 77\% de habitantes da cidade nascidos no estado, sendo $69 \%$ do total na cidade). ${ }^{33}$ A realização da amostragem procurou uma compensação para essa hipertrofia de perfil (do nacional ao regional) por meio da diversificação de unidades da federação para os 23\% de habitantes do estado de São Paulo que não nasceram nele; foram, então, entrevistados 112 indivíduos $(32,6 \%$ da amostragem) naturais dos outros estados brasileiros, à exceção de Acre, Amapá, Distrito Federal, Roraima e Tocantins.

Quanto a suas ocupações profissionais, os entrevistados declararam livremente 118 diferentes funções (sendo 0,05\% desempregados ${ }^{34}$ ); após uma análise preliminar das mesmas, foi possivel agrupá-las em 90, incluindo um leque muito variado que inclui comerciantes, donas de casa, empregadas domésticas, estudantes, funcionários públicos, educadores, operários, empresários, cabeleireiras, agricultores, faxineiros, jornalistas, prostitutas, militares e médicos, dentre outros (ressalte-se que, no momento da pesquisa, nenhum deles se encontrava ligado profissionalmente à História). Nesse quesito é impossivel estabelecer uma perfeita correlação entre a amostragem e o panorama laboral brasileiro; buscou-se apenas incluir uma ampla gama de perfis profissionais.

0 perfil dos entrevistados segundo renda familiar também se mostrou de difícil equivalência com dados do IBGE, já que estes indicam rendas individuais, e não familiares. Assim mesmo, observa-se que a amostragem seguiu uma tendência também de "pirâmide", que faz com que o número de brasileiros dos estratos de renda mais baixa sejam sempre mais numeroso que os de renda mais alta; a diferença entre o conjunto da população brasileira e a amostragem está, seguramente, nas dimensões de tais estratos: enquanto os dados do IBGE mostram mais de $64 \%$ de indivíduos sem rendimentos ou com renda entre 1 e 5 salários mínimos, na amostragem esse percentual (por famílias) pouco passou de $30 \% .^{35}$ 
03/10/2012, pelo SBT. Conforme a sinopse da emissora, "baseado no formato criado pela BBC, The Greats, o programa elege[u] aquele que fez mais pela nação, que se destacou pelo seu legado à sociedade. Diversos paises já apontaram os seus maiores representantes. Na Inglaterra, Winston Churchill saiu vencedor. Os italianos elegeram Leonardo da Vinci" (sbt.com.br/omaiorbrasileiro/ programa. Acesso em 21/03/2014). A escolha dos candidatos e a definição de seus confrontos - os personagens iam se enfrentando programa a programa, em caráter eliminatório - foi feita pelo telespectador, sendo o "campeão" Chico Xavier, seguido por Santos Dummont e pela princesa Isabel. Semelhante, mas de menor alcance, foi a pesquisa realizada pela Revista de História da Biblioteca Nacional, divulgada em abril de 2008, que convocou "para a tarefa de eleger os 'heróis' e os 'vilões' do Brasil uma distinta seleção de historiadores, professores, jornalistas, economistas, políticos e artistas, protegidos pelo anonimato para louvar e condenar quem bem entendessem". Entre os mais bem avaliados estavam Rui Barbosa, Machado de Assis e D. Pedro II; no polo oposto, Médici e Costa e Silva (revistadehistoria.com.br/secao/reportagem/ ranking-dos-brasileiros. Acesso em 21/03/2014).

40

As palavras são: acordo, comédia, continuação, democracia, ditadura, drama, elites/poderosos, escravidão, Estados Unidos, exército, guerra, heroismo, Inglaterra, invenção, João VI, José Bonifácio, liberdade, mudança, nação, nascimento, negociação, paz, Pedro I, Portugal, povo, revolução, Tiradentes, tirania. 0 entrevistado poderia incluir outra palavra qualquer que desejasse.

41

0 questionário encerrava-se com a possibilidade do entrevistado acrescentar livremente algo bem como a opção de identificação nominal. Um proveitoso desdobramento da pesquisa poderia resultar de uma análise de nuances e matizes de interessantes jogos discursivos presentes em muitas das respostas obtidas, sobretudo no caso de uma expansão numérica da amostragem.

42

Quando, em fevereiro de 2013, foram amplamente divulgados resultados de pesquisas biomédicas (com tentativas de conclusões também históricas) realizadas com os restos mortais de Pedro I, Leopoldina e Amélia, realizadas por Valdirene Ambiel. Cfr. AMBIEL, Valdirene do Carmo. Estudos de arqueologia forense aplicados aos remanescentes humanos dos primeiros imperadores do Brasil depositados no monumento à Independência. 2013.

Dissertação. (Mestrado em Arqueologia). Museu de Arqueologia e Etnologia, Universidade de São Paulo, São Paulo, 2013. Além de procurar esclarecer se tais restos se encontravam depositados no Monumento à Independência, em São Paulo, e diagnosticar o estado de conservação dos mesmos, Ambiel procurou chamar a atenção para as possiveis causas da morte dos monarcas e sobre os procedimentos funerários com eles então utilizados. Tais resultados foram divulgados pela imprensa nacional como "verdades" sobre a familia imperial brasileira supostamente ausentes dos livros de história, "segredos" agora "revelados". Por exemplo: Pedro I tinha quatro
No tocante a instrução formal, os dados nacionais oficiais incidem sobre crianças a partir de 10 anos de idade, sendo que a amostragem realizada focou em jovens a partir de 15 anos; desse modo, a aproximação da amostragem com o perfil brasileiro partiu de uma retificação dos números apresentados pelo IBGE. ${ }^{36} \mathrm{E}$ se, em termos de renda familiar, a amostragem mostrou clara inclinação a um perfil excessivamente de classe média, o mesmo pode-se dizer quanto à instrução formal, que perfez um grupo mais escolarizado do que a média do pais. 0 principal problema aqui ocorre no baixo número de entrevistados entre "sem instrução e fundamental incompleto" ( $7 \%$, sendo a porcentagem nacional entre $44 \%$ e $50 \%$ ), em prol de um número por demais elevado de indivíduos que cursaram universidades (27\% contra 9\%); as demais rubricas também apresentam discrepâncias: $25 \%$ de entrevistados entre "fundamental completo e médio incompleto" (contra 19\%), e 23\% entre "médio incompleto e superior incompleto" (contra 26\%). A análise de todo o material obtido, assim como das fontes primárias, levou em conta tais inclinações e, como se verá mais adiante, elas parecem até mesmo reforçar algumas das conclusões aqui obtidas. Ainda no mesmo quesito, os dados do IBGE classificam os brasileiros de acordo com "rede de ensino que frequentavam" quando da realização da coleta de dados, sendo que o questionário abordou os entrevistados de acordo com frequência em curso/já realizada. ${ }^{37}$ Mesmo assim, os números aqui disponiveis serviram bem à constituição da amostragem.

Na segunda parte do questionário, a obtenção do perfil cultural do entrevistado se deu a partir de uma identificação de seu acesso à televisão (se assiste, caso positivo com qual frequência, que tipo de programas, se em tevê aberta e/ou a cabo, e quais os três programas que mais assiste), leitura (se lê com frequência, que tipo de coisa, e quais os últimos três livros que leu), cinema e teatro (em ambos os casos, apenas se costuma ou não frequentar) ${ }^{38}$ Após tais perguntas, que procuraram diagnosticar eventuais proximidades do entrevistado em relação a fontes secundárias da pesquisa, o questionário introduziu a questão especifica de seu interesse pela História. Foi então perguntado se ele se interessa ou não por História, e por qual (do Brasil, geral ou outra/qual?); se busca informações sobre e, em caso positivo, onde (livros, televisão, internet, revistas, cursos, museus, outro/qual?) e se, nos últimos dois anos, leu algo ou frequentou algum curso a respeito (em caso positivo, qual?). Tais perguntas foram elaboradas visando uma aproximação realista com caracteristicas que, de modo hipotético, foram atribuídas a essa cultura de história no Brasil. Por isso, foram preteridas formas linguísticas quiçá muito acadêmicas, em prol de outras que permitissem que o entrevistado se expressasse de modo a fornecer dados válidos; daí, por exemplo, o uso da tradicional divisão entre História do Brasil e História Geral (com abertura para identificação de "outra" qualquer), de muito pouca serventia para os historiadores profissionais.

Finalmente, a terceira parte do questionário visou à obtenção de conteúdos diretamente relacionados à Independência do Brasil, valendo-se mais amplamente ainda dessa estratégia de utilização de formas linguísticas coloquiais, assim como de perguntas cujas respostas seriam tanto dirigidas como abertas: grau de interesse sobre a história da Independência do Brasil (nenhum, pequeno, médio ou grande, seguido de uma justificativa), grau de conhecimento do tema (nenhum, pouco, razoável, bom, excelente), se procura se informar sobre (não, sim/como) e se está lendo ou leu algo a respeito nos últimos dois anos (não, sim/o quê). Ou seja, abriu-se a 
costelas quebradas quando morreu, era mais baixo do que se supunha, não foi cremado, mas enterrado, acompanhado de porções de terra de Portugal e com roupas de general com insignias portuguesas, e não brasileiras. Leopoldina não teve o fêmur quebrado antes de morrer como acreditava-se até então, foi enterrada com a mesma roupa com que foi coroada imperatriz e seus brincos não eram de ouro, mas bijuterias de resina. Já Amélia, quando morreu, tinha escoliose e osteoporose, foi enterrada de preto e mumificada. $\mathrm{Na}$ internet, tais "revelações" foram, no total, comentadas milhares de vezes, "recomendadas" e, em geral, bem-recebidas (fotos.estadao.com.br/mudanca-na-historiadez-verdades-sobre-a-familia-imperialque-nao-estao-nos-livros-de-historia,galer ia,7048, 194910,_,0.htm?pPosicaoFoto=1 \# carousel, acesso em 27/03/2014; folha.uol.com.br/fsp/ cienciasaude/94655-corpos-da-familia-imperialsao-exumados.shtml, acesso em 02/04/2014; folha.uol.com.br/fsp/cienciasaude/94656descoberta-mostra-abandono-de-d-leopoldinadiz-historiadora.shtml, acesso em 02/04/2014; estadao.com.br/noticias/cidades,sob-sigilodom-pedro-i-e-suas-duas-mulheres-saoexumados-pela-primeira-vez,998367,0.htm, acesso em 02/04/2014; veja.abril.com.br/ blog/ricardo-setti/tema-livre/abertura-paraestudos-dos-sarcofagos-de-d-pedro-i-e-desuas-duas-esposas-e-fato-extraordinarioparabens-ao-estadao-por-divulgar-tudo/, acesso em 02/04/2014; br.noticias.yahoo. com/exuma\%C3\%A7\%C3\%A3o-d-pedro-imulheres-reconta-hist\%C3\%B3ria-115400981. html>, acesso em 02/04/2014; g1.globo.com/ ciencia-e-saude/noticia/2013/02/cientistasbrasileiros-exumam-restos-mortais-de-d-pedroi-e-suas-mulheres.html, acesso em 02/04/2014; youtube.com/watch?v=y8jcdXyx3hA>, acesso em 02/04/2014; vestibular.uol.com.br/resumodas-disciplinas/atualidades/historia-do-brasilexumacao-traz-novidades-sobre-d-pedro-i.htm, acesso em 02/04/2014; <google.com.br/search?q= exuma $\% \mathrm{C} 3 \% \mathrm{~A} 7 \% \mathrm{C} 3 \% \mathrm{~A} 30+$ de+dom +pedroctoq $=$ exuma $\% \mathrm{C} 3 \% \mathrm{~A} 7 \% \mathrm{C} 3 \% \mathrm{~A} 30+\mathrm{Ctaqs}=$ chrome.4.69i57j0l5.5749j0j8ctsourceid= chromeftespv $=210$ \&tes_sm $=93$ Ctie $=$ UTF-8 $>$, acesso em 02/04/2014; noticias.seuhistory. com/exumacao-revela-detalhessurpreendentes-da-vida-e-morte-de-dpedro-i-e-suas-mulheres $>$, acesso em 02/04/2014; istoe.com.br/reportagens/277892_ $\mathrm{A}+\mathrm{VOLTA}+\mathrm{DE}+\mathrm{DOM}+\mathrm{PEDRO}+\mathrm{l}$, acesso em 02/04/2014; bahiaatual.com/noticias/ exumacao-de-corpos-de-d-pedro-i-reveladetalhes-da-famiila-real/, acesso em 02/04/2014; Site Último Segundo "Exumação de D. Pedro I e suas mulheres reconta a História", disponivel em ultimosegundo.ig.com.br/ ciencia/2013-02-19/exumacao-de-dpedro-i-esuas-mulheres-reconta-a-historia.html, acesso em 02/04/2014; diariodepernambuco.com. br/app/noticia/ciencia-e-saude/2013/02/19/ internas_cienciaesaude,424273/restos-mortaisde-d-pedro-i-sao-exumados-para-realizacaode-pesquisa.shtml, acesso em 02/04/2014; http://opiniaoenoticia.com.br/brasil/restosmortais-de-dom-pedro-i-sao-exumados/>, acesso em 02/04/2014; noticias.band.uol.com.br/ jornaldaband/conteudo.asp?id $=100000576688$, acesso em 02/04/2014. possibilidade de se chegar a dados de uma cultura de história inclusive em suas negações, em seus silêncios e interdições. Em seguida, o questionário recorreu a um artifício muito presente no meio social sobre o qual incidiu: foi pedido ao entrevistado que atribuísse notas, de um a dez, para a importância que acha que a Independência teve para a história do Brasil e para a história do mundo. Nos historiadores profissionais em geral, esses rankings, com sua gigantesca capacidade de simplificar a realidade, costumam despertar ojeriza; no entanto, para os demais agentes sociais dessa cultura, pode significar uma forma útil de representação da realidade, acostumados que estão a ela em muitos aspectos de sua vida cotidiana. ${ }^{39}$ Assim, também daqui pode-se extrair elementos para a análise de uma cultura de história. Já as três perguntas seguintes buscaram outra aproximação: foi pedido ao entrevistado que, diante de uma lista de 28 palavras, escolhesse as três que acreditasse que mais combinam e as três que menos combinam com a Independência. ${ }^{40}$ Tais palavras incidem sobre personagens, fatos, processos, conceitos e mitos, constituindo um bom leque de possibilidades de aproximação linguística e conceitual com formas de ver a Independência presentes na sociedade, inclusive por contemplarem vários antinômicos. Por fim, perguntou-se ao entrevistado se seria capaz de dizer as datas $d a$ chegada da corte portuguesa no Brasil, da Independência do Brasil, da primeira Constituição e da abdicação de D. Pedro I. ${ }^{41}$ Aqui, o intuito era aferir até que ponto essa cultura de história se organiza e se faz representar por marcos cronológicos convencionais, bem como se enseja formas alternativas de historicização e temporalização.

Desse modo, por meio de estratégias de abordagem complementares (graus de relação ativa ou passiva diante do tema; o peso de linguagens, conceitos e informações; formas temporais) o questionário procurou fazer convergirem possibilidades de posturas dos entrevistados em relação à história e à Independência do Brasil, bem como dimensões variadas e eventualmente contraditórias de tais posturas, relacionando-as, inclusive, com as cinco perguntas básicas que seriam posteriormente dirigidas às fontes secundárias, conforme enunciado ao final do item anterior.

Após um curto período de testes, foram entrevistadas presencialmente 311 pessoas na cidade de São Paulo, Grande ABC e interior do estado, entre os dias 19 de setembro de 2012 e 02 de agosto de 2013. Propositadamente, foram evitadas as duas Semanas da Pátria desses anos, bem como um periodo de vinte dias de superexposição midiática específica do tema. ${ }^{42}$ As abordagens foram realizadas de modo direto, em 99,4\% das vezes em espaços públicos, tendo cada uma - com poucas exceções -a duração de cerca de sete minutos, durante os quais evitou-se ao máximo qualquer tipo de constrangimento, direcionamento ou auxílio nas respostas.

0 que foi possivel obter nessas entrevistas? Os entrevistados compõem um grupo de forte contato com a televisão (93\% assistem com frequência e $51 \%$ todos os dias, sendo que $58 \%$ possuem tevê aberta e a cabo; apenas 6\% disseram não assistir tevê), de leitores frequentes (78\%), e de assistentes a cinemas (58\%) e teatros (28\%), o que o aproxima de um perfil de classe média escolarizada, conforme já apontado anteriormente; de todo modo, há que se lembrar que, em muitos outros aspectos relevantes, esse é um grupo heterogêneo. Daí a importância do fato de que 77\% dos que o compõem disseram se interessar por história (sendo que $60 \%$ afirmaram buscar informações a respeito). Esse é um número alto ou baixo? A questão não parece das mais importantes, já que, de acordo com a 
Não parece ser o caso da cultura histórica portuguesa, de acordo com trabalhos recentes como os de PAIS, José Machado. Op. Cit.; SOBRAL, José Manuel. Op. Cit.; e MATOS, Sérgio Campos. Consciência histórica e nacionalismo: Portugal, séculos XIX e XX. Lisboa: Horizonte, 2008.

44

A ausência de menções a outros tipos de suporte de informações sobre a Independência reforça a escolha das fontes secundárias da pesquisa, analisadas no próximo item.

45

Embora seja muito frequente a consideração de que o principal marco fundacional da história brasileira tenha sido o "descobrimento" (isto é, a chegada dos portugueses à América em 1500), e não a ruptura política entre Brasil e Portugal. Muito provavelmente, isso se conecta com uma também muito frequente concepção da Independência como "não-ruptura", como processo negociado, amigável e sem grandes solavancos. Retornaremos à questão.

46

Todas as 28 palavras oferecidas aos entrevistados receberam no mínimo quatro menções, sendo que 22 tiveram mais de uma dezena de menções, a mesclarem termos que remetem a caracteristicas atribuídas à Independência, que ensejam relações diretas ou indiretas com ela, ou que se referem a simples informações.

47

Foram feitas 310 menções de termos positivos em relação à Independência (liberdade, democracia, revolução, heroísmo, mudança, drama), contra 210 dos mesmos como não combinando com ela; essa tendência é reforçada por 190 menções a termos negativos que combinariam com ela (acordo, escravidão, negociação, continuação, ditadura, comédia, invenção, tirania), sendo que os mesmos foram mencionados 391 vezes como não combinando. Esclarecer o caso de escravidão: pode ser referência a uma realidade (em geral, negativa), mas também como metáfora política. Para todos os efeitos, como mencionar o termo de outras maneiras?

48

148 escolhas incidiram sobre termos conflitivos que com ela combinariam (guerra, revolução, mudança), contra 101 menções a tais termos como não combinando; porém, tal tendência se inverte nas 119 escolhas de termos pacíficos que com ela combinariam (paz, acordo, negociação), contra 70 menções aos mesmos como não combinando.

49

Foram feitas 27 escolhas de povo como combinando contra 22 do mesmo termo como não combinando, e 35 a elite/poderosos como combinando, contra $14 \mathrm{em}$ termos opostos, o que indica certo equilibrio tendente à segunda possibilidade.

50

Não se pode deixar de mencionar algumas outras palavras que não se encontravam na lista, mas foram acrescidas pelos entrevistados, sendo, portanto, de menção espontânea. As mais recorrentes, combinando num sentido depreciativo foram "interesse" e "corrupção" Outras palavras, tais quais, "unificação", "morte" definição aqui proposta de cultura de história, o desinteresse também é um dado relevante, pois traduz uma atitude em si, e que dificilmente poderia ser considerada de modo absoluto (como pretender que esse desinteresse se traduza, por exemplo, em descaso com a própria história ou com a da família? Difícil acreditar ser esse o caso de 23\% dos entrevistados). Além disso, bem sabemos que seu contrário, o interesse, pode se manifestar de muitas maneiras que não necessariamente encontram guarida em práticas acadêmicas e profissionais relacionadas ao estudo do passado, tampouco que resultam em um estudo da história minimamente organizado. 0 que implica que os dois contrários nem sempre estabelecerão limites claros entre si: diante da apreciação geral de uma cultura de história, interesse e desinteresse pela história podem flertar com muita proximidade, bem como intercambiarem elementos regularmente.

Observemos mais atentamente esse panorama. Considerando-se tais caracteristicas de uma cultura de história como a brasileira, perguntou-se a todos os entrevistados, incluindo aos 23\% que afirmaram não se interessar por história, por "qual história" poderia dizer que mais se interessa. Aqui, as respostas que de alguma forma se referem diretamente à história do Brasil ("História do Brasil", "História geral e do Brasil", "História da nossa região", "História do Brasil e andina") perfazem 34\% do total, aí sim um número relativamente baixo diante dos $66 \%$ que em suas respostas excluíram o Brasil. Portanto, independentemente do interesse pela matéria ser alto ou baixo, a relação com a História do Brasil parece gozar de especial desprestígio. Será o desprezo pela história nacional um dado da cultura de história no Brasil? ${ }^{43}$ Mais adiante, quando da análise das outras fontes, voltaremos a esse ponto. De todo modo, tal desprestígio evidentemente trará implicações para as posturas dos brasileiros em relação à Independência.

A princípio, os entrevistados tendem a se interessar pouco pela Independência do Brasil, mas essa não é uma tendência absoluta: se 39\% têm "nenhum", "pouco" ou "pequeno" interesse, 44\% tem "médio", e 17\% "entre médio e grande" e "grande". Ora, em se tratando de uma cultura de história dinâmica e fluida, com fronteiras pouco claras entre o interesse e o desinteresse pela história de modo geral (e a despeito da clara tendência a um maior desinteresse pela História do Brasil), a Independência é pouco interessante, mas não é inteiramente desprezada (apenas 11\% declararam "nenhum" interesse por ela, cifra menor do que a dos grandes interessados).

Parece então haver espaço, aqui, para diferentes formas de pensar, representar e reinventar a Independência do Brasil, como verificar-se-á mais adiante; de momento, constata-se uma correspondência estatística entre os 17\% que por ela se interessam, os 16\% que disseram ter dela "bom" ou "excelente" conhecimento (os de "nenhum", "pouco" ou apenas "razoável" conhecimento compõe os demais 83\%), e os 30\% que afirmaram buscar informações a respeito (sendo $60 \%$ os que buscam informações sobre história em geral). Provavelmente, trata-se de um subgrupo dos mais ativos no circuito de consumo-reprodução-criação de tópicos relativos à Independência na cultura de história no Brasil. Dentre esses 30\% exclusivamente, 30,5\% afirmaram buscar informações sobre a Independência em livros, $29,1 \%$ na escola e nos livros didáticos (evidentemente mais confinados ao público jovem), 20,8\% na internet, 9,7\% em rádio, tevê e/ou jornais impressos, e outros 9,7\% "com pessoas e lugares ${ }^{44}$. Os que responderam ler ou ter lido algo a respeito nos últimos dois anos foram 34\% (os demais responderam "não"|"não se lembra", ou não responderam). 
(em alusão ao Grito) e "progresso", enriqueceram a fileira dos termos valorativos.

51

Essa percepção é reforçada por alguns dos dados obtidos por Purificação. Em meio a representações da Independência produzidas por crianças entre 09 e 13 anos, encontram-se frases como "Quando D. Pedro viu terra, gritou: Independência ou Morte!", e "Pouco depois de descobrirem o Brasil, gritaram a independência". PURIFICAÇÃO, Ana Teresa da. 0p. Cit., p.40-41. Cabe lembrar que tais crianças não haviam tido ainda contato formal (na escola) com o tema da Independência, "apenas" por meio de uma cultura de história a envolverem-nas.

52

0 que parece impor uma urgente reflexão em torno dos efeitos do violento desprestígio das referências factuais que o sistema escolar impôs ao ensino de História no Brasil das últimas décadas. 0 quê, ademais, não parece uma situação exclusivamente brasileira, de acordo com a sugestão que nos foi dada por Nuno Gonçalo Monteiro, a ver aqui paralelismo com o ensino de História em Portugal.

53

Outras duas possibilidades promissoras seriam analisar respostas a questões de vestibulares relativas à Independência, e entrevistas com professores e coordenadores pedagógicos que, de alguma forma, lidem com o tema no cotidiano escolar.

54

MORENO, Jean Carlos. Limites, escolhas e expectativas: horizontes metodológicos para análise dos livros didáticos de história. Antíteses, Londrina, v.5, n.10, p.729, jul./dez.2012.

55

0 que é atestado, por exemplo, pela recente consolidação da presença, nos livros didáticos, de tópicos relativos à História do continente africano.

56

Dos 49 autores de livros didáticos aqui considerados, 36 são identificados pelos termos "mestre", "doutor" ou "professor universitário". 0 que não significa, como é bem sabido, que tais autores sejam integralmente responsáveis pelo conteúdo de suas obras.

57

MORENO, Jean Carlos. Op. Cit., p.724.

58

Segundo dados oficiais, somente no ano de 2012, esse governo comprou cerca de 40,8 milhões de livros didáticos para os anos do Ensino Médio (Assessoria de Comunicação Social do FNDE, 24 de agosto de 2012).

59

Sua produção, no entanto, é regionalmente concentrada: na seleção das coleções de didáticos feita pelo MEC em 2010, oito editoras de São Paulo responderam por $84,2 \%$ da produção aprovada, enquanto três de Curitiba ficaram com os $15,8 \%$ restantes.

60

DIAS, Adriana M., GRINBERG, Keila e

PELLEGRINI, Marco. Novo Olhar. História. v.2. São
A hipótese da constituição de um subgrupo ativo na cultura de história por meio do tema da Independência encontra respaldo nos resultados do ranking do questionário: para a importância que ela teria tido para a História do Brasil, 43\% deram nota 10, e outros 31\% notas entre 8 e 9 , sendo que apenas $6 \%$ deram notas entre 0 e 4 ou não souberam responder. Ou seja, mesmo quem não se interessa pela Independência ou pela História do Brasil em geral, tende a reconhecer o tema como sendo de grande importância, embora tal reconhecimento seja menor em se tratando de sua relação com a História "em geral" (a essa pergunta, 25\% respondeu com nota 10 , e outros $25 \%$ com notas 8 ou 9 , em contraposição a um elevado percentual de $22 \%$ que deu notas entre 0 e 4 , ou não soube responder). Ainda assim, portanto, a Independência é fortemente valorizada por um percentual que extrapola os 17\% que por ela se interessam, os 16\% que disseram dela serem conhecedores ou os 20\% que afirmaram buscar informações a seu respeito. Valorizada, porém, em meio ao que parece ser uma dificuldade de se pensá-la para além de sua tradicional circunscrição nacional (o que encontra, como logo veremos, enorme correspondência nas fontes secundárias), para além dos limites a ela convencionalmente impostos por tradições historiográficas ainda fortes, e mesmo por uma cultura de história que, tendo atributos fortemente nacionais, tende a nela enxergar um marco fundacional importante; isto é, um marco diferenciador entre a história do Brasil e a de outros paises. ${ }^{45}$

0 que, nesse sentido, nos mostram as escolhas de palavras que "combinam" e "não combinam" com a Independência? ${ }^{46}$ Em primeiro lugar, a possibilidade da Independência ser vista mais em perspectiva positiva/enaltecedora do que negativa/depreciativa. ${ }^{47} \mathrm{Em}$ segundo lugar, a possibilidade da Independência ser considerada tanto como ruptura/conflitiva quanto como continuidade/pacífica. ${ }^{48} \mathrm{Em}$ terceiro lugar, a possibilidade da Independência ser vista como algo menos popular do que elitista. ${ }^{49} \mathrm{Em}$ quarto e último lugar: até que ponto os entrevistados se mostraram conhecedores da história? 55 respostas indicaram termos informativos descabidos (Tiradentes combina; D. Pedro I, D. João VI, José Bonifácio e Portugal não), contra uma maioria de 190 menções a tais termos de modo inverso. Aqui, os resultados podem indicar a prevalência de um tipo de conhecimento de história estruturado em personagens e trajetórias individuais (como logo veremos, as fontes secundárias também referendarão amplamente essa hipótese). ${ }^{50}$

$\mathrm{Na}$ última parte do questionário perguntou-se aos entrevistados acerca de datas de quatro eventos que podem ser considerados como marcos do processo de Independência. 68\% responderam não saber ou não se lembrar da data da chegada da Corte portuguesa ao Brasil; 13\% deram respostas claramente erradas, em muitas das quais ("mil e quinhentos", "mil quinhentos e oito", "mil oitocentos e oitenta e oito", etc.), não obstante, se vislumbra uma referência adequada, porém tratada de modo equivocado; e somente 9\% souberam responder de modo preciso ("mil oitocentos e oito"). Diante da pergunta quanto à data da primeira constituição do Brasil, 85\% disseram não saber ou não se lembrar; 7 \% deram respostas claramente erradas ("mil e quatrocentos", "mil quinhentos e oitenta"), algumas das quais, porém, se aproximando da evocação de alguma constituição brasileira ("mil oitocentos e oitenta e oito", "mil oitocentos e oitenta e nove", "mil novecentos e trinta", "mil novecentos e oitenta e oito"); e apenas $13 \%$ souberam responder com firmeza, isto é, com a presença de "mil oitocentos e vinte e quatro" na resposta. Já a pergunta sobre a data 
Paulo: FTD, 2010; ALVES, Alexandre e OLIVEIRA Letícia F. de. Conexões com a História. v.2. São Paulo: Moderna, 2010; PEDRO, Antônio e LIMA, Lizânias de Souza. História sempre presente. v.2. São Paulo: FTD, 2010; VICENTINO, Cláudio R. e DORIGO, Gianpaolo F. História Geral e do Brasil. v.2. São Paulo: Scipione, 2011; FIGUEIRA, Divalte G. História em foco. v.2. São Paulo: Ática, 2011; NOGUEIRA, Fausto G. e CAPELLARI, Marcos. Ser protagonista. História. $2^{\circ}$ ano do Ensino Médio. São Paulo: Edições SM, 2010; BURITTI, Flávio. Caminhos do Homem. v.2 Curitiba: Base Editorial, 2010; CAMPOS, Flávio de; CLARO, Regina. A escrita da História. v.2, São Paulo: Escala Educacional, 2010; COTRIM, Gilberto. História Global: Brasil e Geral. v.2. São Paulo: Saraiva, 2010; AZEVEDO, Gislane C. e SERIACOPI Reinaldo. História em movimento. v.2. São Paulo: Ática, 2010; MORENO, Jean Carlos e GOMES, Sandro V. História: cultura e sociedade. v.3. Curitiba: Positivo, 2010; FERREIRA, João Paulo e FERNANDES, Luiz Estevam. Nova História integrada. v.2. 2a. ed. Curitiba: Módulo, 2010; MORAES, José Geraldo Vieira de. História Geral e Brasil. v.2. São Paulo: Saraiva, 2010; BRAICK, Patricia e MOTA, Myriam B. História. Das cavernas ao terceiro milênio. v.2. 2a. ed. São Paulo: Moderna; SANTIAGO, Pedro, CERQUEIRA, Célia e PONTES, Maria Aparecida. Por dentro da História. v.2. São Paulo: Escala Educacional, 2010; MOCELLIN, Renato e CAMARGO, Rosiane. História em debate. v.2. São Paulo: Editora do Brasil, 2010; CATELLI Jr., Roberto; GANDINI, María Soledad M. e ASPIS, Renata L. História texto e contexto. v.2. São Paulo: Scipione, 2011; FARIA, Ricardo de M.; MIRANDA, Mônica Liz e CAMPOS, Helena. Estudos de História. v.2. São Paulo: FTD, 2010; VAINFAS, Ronaldo; FARIA, Sheila de Castro; FERREIRA, Jorge Luis;

SANTOS, Georgina dos. História. v.2. São Paulo: Saraiva, 2010.

61

PURIFICAÇÃO, Ana Teresa da. Op. Cit. 62

Conforme observou o Guia de livros didáticos: PNLD 2012: História, 17 das coleções aprovadas adotaram a perspectiva da História Integrada, na qual se expõe o conteúdo histórico a partir da "sequência cronológica de base europeia", havendo o predomínio da "História Geral eurocêntrica" linear. Os assuntos sobre a História da América e do Brasil estão intercalados nesta grande História Geral. As outras duas coleções optaram pelo formato temático, organizando os assuntos "em torno de múltiplos espaços e temporalidades", mas guiados por um eixo cronológico. Guia de livros didáticos: PNLD 2012: História. Op. Cit., p. 18-19.

63

Uma afirmação típica: "0 nascimento do Brasil como país independente encontra-se dentro do contexto de crise do Antigo Regime e do sistema colonial mercantilista." VAINFAS, Ronaldo; FARIA, Sheila de Castro; FERREIRA, Jorge Luis; SANTOS, Georgina dos. Op. Cit., p.89. Os paradigmas historiográficos a que tal tipo de afirmação remete são, evidentemente, as obras de Caio Prado Júnior e Fernando Novais, já amplamente presentes também nos livros de Ensino Fundamental. PURIFICAÇÃO, Ana Teresa da. Op. Cit., cap.3. da abdicação de D. Pedro I foi a campeã em respostas imprecisas: $92 \%$ disseram não saber ou não se lembrar, 1,6 \% deu respostas erradas, e apenas $1,2 \%$ soube responder "mil oitocentos e trinta e um".

E quanto à data da Independência do Brasil? Em comparação com as perguntas anteriores, esta obteve respostas de qualidade superior, não obstante um número ainda alto de respostas "não soube" e "não lembra": $33 \%$ dos entrevistados. Há que se lembrar, inclusive, que desde a segunda parte do questionário, o entrevistado já sabia tratar-se de algo focado na Independência; ou seja, se nas demais perguntas pode-se dizer que ele foi pego totalmente surpresa, nesta não. Por isso, e se considerarmos ainda os $14 \%$ que deram respostas claramente erradas a esta pergunta ("mil e quinhentos", "vinte e um de abril de mil e quinhentos", "vinte e dois de abril de mil e quinhentos", "mil oitocentos e oitenta e nove", "vinte e um de abril", "vinte e dois de abril", "nove de julho"), chega-se a um total de $47 \%$ de pessoas incapazes de dizer quando ocorreu a Independência do Brasil. Por outra parte, os que souberam responder ("sete de setembro de mil oitocentos e vinte e dois" ou "mil oitocentos e vinte e dois") chegaram a 16\%, índice muito próximo das dimensões do hipotético grupo de interessados e razoáveis conhecedores da História da Independência, referido alguns parágrafos acima.

Trata-se de um número elevado, ainda mais se reafirmarmos que a Independência não é jamais completamente ignorada em meio à cultura brasileira de história? De certo modo, sim; mas não deve escapar à observação de ninguém que, nessa pergunta específica, a confusão de datas se dá dentro de referências históricas e cronológicas bastante demarcadas: a Independência, o "descobrimento do Brasil", Tiradentes e a Proclamação da República, todos eles marcos fundacionais em uma memória histórica oficial, logo fundamentais na constituição de uma cultura de história no Brasil. ${ }^{51}$ Tais resultados indicam, preliminarmente, a precariedade da concepção de história - da Independência em particular - segundo formas convencionais de organização cronológica; e isso a despeito dessa sociedade ser permeada e carregada de referências cronológicas que organizam a vida das pessoas em muitos de seus interstícios (vida familiar, vida profissional, práticas de lazer e de culto, etc.). Pouquíssimas respostas - estatisticamente desprezíveis -parecem esboçar a forja de alguma modalidade alternativa de organização temporal da história ("quase duzentos anos", "mil oitocentos e alguma coisa", ou "D. Pedro saiu para brigar com o irmão e deixou D. Pedro II"), diante do quê ganha força a hipótese de uma enorme e generalizada dificuldade, apresentada por essa sociedade, no manejo de recursos básicos de historicização da história, como a cronologia. ${ }^{52}$

Até aqui, as conclusões a que se pode chegar ainda são excessivamente parciais, extraídas apenas da sondagem de opinião; convém, no entanto, sumarizá-las, de modo a reforçá-las como hipóteses capazes de nortear a análise vindoura. Segundo o que nos mostram os entrevistados, a Independência é pouco frequentada por muitos, mas assiduamente por um grupo razoável (serão seus membros os únicos capazes de pensá-la segundo marcos cronológicos?); é amplamente considerada tema da maior importância para a História do Brasil, e de menor importância para a História do Mundo; ela é menos interessante do que outros temas (quais, não sabemos), assim como a História do Brasil é menos do que a História Geral, mas tende a ser vista como algo respeitável, eventualmente positivo para o Brasil, o que parece evocar um imaginário oficial ainda muito vigente de 
Exemplo é a afirmação de que "em reconhecimento à importância da Batalha do Jenipapo como um episódio fundamental no processo de independência e de consolidação do território, a data de 13 de março de 1823 foi estampada na bandeira do estado do Piauí". DIAS, Adriana; GRINBERG, Keila e PELLEGRINI, Marco. Op. Cit. p.240.

65

Excelente demonstração é dada por uma proposta pedagógica de um jogo didático elaborado pelo Laboratório de Ensino de História da Universidade Federal de Pelotas, descrita em: GASPAROTTO, Alessandra; ESPÍRITO SANTO, Marco Vinício do; SILVA, Eduarda Borges da. Jogo didático vira-vira: a metrópole vira colônia, a colônia vira-metrópole. Revista Latino-Americana de História, v.2, n.6, agosto de 2013 (Edição Especial), p.648-661.

66

Os preferidos são D. João, Carlota Joaquina, José Bonifácio e D. Pedro.

67

Um exemplo: após afirmar que "durante anos, a historiografia oficial tentou idealizar o processo de independência e seus autores, explicado como um ato de heroismo contra a tirania e em defesa da liberdade", uma das obras afirma, em tom de contraposição: "Mas, nas últimas décadas, novos estudos permitiram lançar um novo olhar sobre esse periodo. Expressões dessa mudança são algumas produções culturais recentes que tratam desse momento com uma visão crítica e até mesmo sarcástica, como, por exemplo, o romance 0 Chalaça (1999), de José Roberto Torero". Por fim, propõe como "Sugestão de atividade", supostamente para aguçar o senso crítico do aluno, "comparar o romance de Torero citado acima com a visão oficial dos eventos fornecida pela célebre pintura Independência ou morte (0 Grito do Ipiranga), de Pedro Américo, ou pelo filme Independência ou morte (1972), de Carlos Coimbra" (BRAICK, Patricia e MOTA, Myriam. Op. Cit., p.80-81). Além de ignorar os momentos, objetivos e naturezas distintos das obras recomendadas, tal atividade sugere a ultrapassagem de uma visão "tradicional" da Independência por outra, "crítica" - logo mais aceitável. Assim, o aluno é encorajado a conceber a história por meio de sua livre-interpretação, mas sendo impelido a endossar a de um romance satírico (logo voltaremos a ele).

68

Em um livro para o Ensino Fundamental, de 1996, lia-se que "para a realização do nosso trabalho foi importante a participação de Mariana Massarani, artista que desenhou, com alegria e bom humor, os acontecimentos estudados" (AQUINO, Rubim de; LOPES, Osca P. Campo; PIRES, Maria Emília B. Do mundo indígena ao período regencial no Brasil. Rio de Janeiro: Ao Livro Técnico, 1994, p.1; citado por PURIFICAÇÃO, Ana Teresa da. Op. Cit., p.79). Essa é uma tendência antiga, como nos mostra 0 poema de Murilo Mendes, "A pescaria" (publicado em História do Brasil, de 1932), evocativo da tão célebre quanto historicamente irrelevante disenteria de D. Pedro em 7 de setembro de 1822 e transcrito em outro didático: "Foi nas margens glorificação da Independência, laudatório e a destacar seus personagens centrais. No entanto, tal tendência encontra obstáculo em outras contrárias, minoritárias, mas não despreziveis, a verem a Independência como algo pouco ou nada importante, uma história restrita espacialmente e socialmente, e mais de continuidades do que de rupturas.

Assim, já é possivel afirmar que a Independência enseja disputas a seu respeito, em torno de suas representações e memórias oficiais ou não. Muito provavelmente, alguns dos motivos que explicam sua rejeição por muitos explicam igualmente sua ativa e entusiasmada frequência por um grupo menor. Em uma terceira via, ela jamais deixou de ser pensada e divulgada em perspectivas complexas, fortemente críticas e analíticas. Para todos os efeitos, a Independência contribui, sem dúvida, para tipificar uma cultura de história no Brasil plural, variada e apenas parcialmente organizada em padrões cronológicos (temporais?), na qual ocupa um papel central, e da qual irradiam outros elementos valiosos para um melhor entendimento dessa mesma cultura.

\section{4 - A Independência nas escolas.}

A principal fonte de fomento e irradiação de atitudes do brasileiro diante da Independência é o sistema escolar, com sua diversidade de agentes, espaços, procedimentos, materiais e valores. Aqui, será analisado apenas um componente, prenhe de significados, desse sistema: o livro didático. ${ }^{53}$

Segundo um estudioso da matéria, os autores de livros didáticos de História em geral - grupo no qual ele mesmo está incluído -"não têm por objetivo somente transpor a História acadêmica, eles identificam necessidades sociais, estão imersos na sociedade e, portanto, na própria história sobre a qual escrevem".54 Tais livros são, assim, documentos privilegiados de uma cultura de história: trazem conteúdos de acordo com padrões e parâmetros de uma sociedade à qual servem, sendo inclusive cada vez mais sensiveis a impulsos de origem não acadêmica; ${ }^{55}$ contam com a colaboração ou autoria de historiadores profissionais ${ }^{56}$ que trabalham junto a editores, assistentes, revisores, iconógrafos, diagramadores e designers gráficos: ${ }_{1}^{57}$ são consumidos preferencialmente por educadores e educandos, mas chegam também às familias destes e ao público em geral; tendem a permanecer por algum tempo disponiveis em salas de aula, residências, livrarias e bibliotecas; e são fortemente condicionados pelas exigências de um grande mercado editorial, cujas demandas capitalistas não são menos evidentes do que as pedagógicas. 0 livro didático é o segundo suporte de leitura mais lido no Brasil, sendo sua produção o mais lucrativo negócio de uma indústria editorial brasileira que tem no governo federal seu maior cliente. ${ }^{58}$ Essa produção dos livros didáticos movimenta enormes cifras, veicula páginas e páginas de conteúdos de História produzidos por e destinados a um amplo conjunto de agentes sociais, e têm circulação nacional..$^{59}$

A Independência está presente em todos os 21 livros destinados ao Ensino Médio aqui considerados, ${ }_{1}^{60}$ assim como estava em outros 12 de Ensino Fundamental contemplados por um estudo acadêmico a respeito. ${ }^{61}$ Nessa dupla frente, abre-se uma possibilidade de análise valiosa, já que alguns livros circulam atualmente, enquanto outros circularam à época em que jovens adultos que hoje têm entre 22 e 26 anos eram crianças entre 9 e 13. Unem-se, assim, duas temporalidades de tratamentos da Independência que podem ser unificadas por uma cultura de história. 
do Ipiranga/Em meio a uma pescaria,/Sentindo-se mal, D. Pedro/Comera demais cuscuz./Desaperta a braguilha/E grita, roxo de raiva:/Ou me livro desta cólica/Ou morro logo de uma vez!/0 príncipe se aliviou,/Sai no caminho cantando:/Já me sinto independente./Safa! Vou de perto a morte!/ Vamos cair no fadinho/Pra celebrar o sucesso". MACEDO, José Rivair. Brasil - uma história em construção. São Paulo: Brasil, 1996, p.166. Cit. por PURIFICAÇÃO, Ana Teresa da. Op. Cit., p.101.

\section{9}

Tomemos por exemplo esta afirmação: "De acordo com alguns historiadores, as raizes da independência brasileira estão na segunda metade do século XVIII, quando se multiplicaram atividades produtivas e comerciais na colônia, sobretudo na região Centro-Sul." (MORAES, José Geraldo Vieira de. Op. Cit., p.113). Nela, é possivel reconhecer a presença de influente e importante interpretação acadêmica acerca da Independência do Brasil (DIAS, Maria Odila. A interiorização da metrópole (1808-1853). In: MOTA, Carlos Guilherme. 1822: dimensões. São Paulo: Perspectiva, 1972. p.160-184.); no entanto, não é apresentada qualquer contraposição (se esta posição é da parte de "alguns historiadores", outra divergente deve ser da parte de outros). Mais adiante, lê-se que "o fato relevante foi que a transferência da corte para o Brasil provocou uma inversão histórica de modo significativo e irreversivel nas relações entre a metrópole portuguesa e a colônia brasileira." (Idem, p.114). Ora, o que seria uma inversão irreversível dessas relações? Portugal teria se tornado para sempre colônia do Brasil?

70

Nos livros didáticos de Ensino Fundamental analisados por Purificação já eram abundantes as transcrições de trechos de textos de historiadores profissionais, sem que deles resultasse qualquer ensejo de pluralidade de pensamento ou de estímulo à interpretação.

71 VAINFAS, Ronaldo; FARIA, Sheila de Castro: FERREIRA, Jorge Luis; SANTOS, Georgina dos. Op. Cit., p. 103.

\section{2}

0 capitulo 14 de uma das obras, intitulado "O processo de independência da América portuguesa", inicia-se com um excerto do Romanceiro da Inconfidência, de Cecília Meireles, também indutor a essa interpretação: "Através de grossas portas / sentem-se luzes acesas / e há indagações minuciosas / dentro das casas fronteiras / Que estão fazendo, tão tarde? / Que escrevem, conversam, pensam? / Mostram livros proibidos? / Leem noticias nas Gazetas?| Terão recebido cartas/de potências estrangeiras? [...] / Ó vitórias, festas, flores / das lutas da Independência! / Liberdade - essa palavra / que o sonho humano alimenta: / que não há ninguém que explique, / e ninguém que não entenda!" (BRAICK, Patrícia e MOTA, Myriam. Op. Cit., p. 202). Já nas "sugestões de leitura e consulta para o professor" de outra, encontra-se indicação de uma obra de J. J. Chiavenato - Inconfidência mineira: as várias faces. São Paulo: Global, 2000 - com este comentário: "o autor mostra o movimento que buscava a emancipação política do Brasil. Adotando uma abordagem que parte da realidade socioeconômica do periodo, este livro releva diferentes aspectos desse momento singular da história brasileira" (NOGUEIRA, Fausto
Não há dúvida que a maioria dos livros didáticos de História voltados ao Ensino Médio abre possibilidades de construção de um conhecimento acerca da Independência multifacetado, matizado, crítico e criterioso, e deles pode-se extrair muitos exemplos a revelarem diálogos propositivos entre saberes acadêmicos e didáticos da História (afinal, os próprios autores e avaliadores dos livros estão quase todos diretamente ligados ao meio acadêmico); aliás, em comparação com os de Ensino Fundamental de cerca de uma década atrás, essas possibilidades só cresceram. Porém, como não é objetivo deste estudo analisar tais livros em si mesmos -somente deles extrair elementos que tipifiquem uma cultura de história por meio da Independência - mais relevantes parecem ser justamente alguns de seus pontos sensiveis, nos quais tais livros se fazem menos acadêmicos e nos quais se traduzem de modo mais significativo componentes mais amplos da sociedade que lhes dá sentido.

Em todos esses livros, a Independência é invariavelmente vista como parte de um processo mais amplo no qual se incluem outros acontecimentos políticos americanos e europeus de finais do século XVIII e começos do século XIX (embora quase nunca sejam feitas conexões fundamentais entre eles, deficiência notável, sobretudo, no tocante às independências da América espanhola, vistas sempre como supostos contraexemplos da Independência do Brasil ${ }^{62}$ ). 0 episódico se faz presente na menção a vários temas menores - a vinda da Corte, a abertura dos Portos, o governo de D. João no Rio de Janeiro, a Revolução de Pernambuco, a Revolução do Porto, etc. - mas sempre em observância a contextos históricos espaciais e temporais mais amplos. ${ }^{63}$ Destaque-se que $80 \%$ dos livros fazem referência explícita ao termo "guerra(s) de independência", ${ }^{64}$ o que enseja uma concepção também multirregional do tema, e vários o aprofundam. 0 mesmo pode ser dito de perfis biográficos, presentes mas submetidos a uma lógica processual da História.

Essa ênfase em processos, em detrimento parcial de acontecimentos e personagens, é importante indício de uma sintonia entre saberes acadêmicos e não acadêmicos. ${ }^{65}$ Contudo, deve-se relativizar o peso desse diálogo já no que tange ao tratamento dispensado às biografias: além de pouco ou nada inovarem na escolha dos personagens destacados; ${ }_{i}^{66}$ alguns livros didáticos trazem fragmentos anedóticos de tais trajetórias, hoje em dia pouco ou nada úteis a historiadores profissionais (embora as comilanças de D. João, os amantes de D. Carlota ou as noitadas de D. Pedro não os distingua de outros agentes históricos de sua época, tampouco são tratados como típicos ${ }^{67}$ ). Parece razoável argumentar que, ao menos parcialmente, tal insistência da parte do livro didático atende ao gosto do leitor/ consumidor, tornando tais suportes materiais mais agradáveis e sedutores; assim sendo, constata-se justamente um limite no diálogo entre saberes acadêmicos e saberes didáticos expressos em tais livros, bem como se anuncia uma tendência de representação humorística do passado em uma cultura de história como a brasileira, muito forte em outros suportes. ${ }^{68}$ Eis um mercado - que no Brasil mescla dimensões editoriais e midiáticas com outras educacionais e culturais mais amplas - impondo seus padrões de representação do passado.

Além de envolverem historiadores profissionais em sua produção e avaliação, os livros didáticos de Ensino Médio parecem esforçar-se, cada vez mais, em trazer conteúdos extraídos de obras acadêmicas, bem como apresentar ao leitor uma pluralidade de posições acerca de um determina- 
e CAPELLARI, Marcos. 0p. Cit., p.71). Em uma terceira obra, logo na abertura de um capítulo intitulado "A independência política do Brasil", lê-se que "os dias 21 de abril e 7 de setembro, feriados nacionais, nos fazem lembrar de dois momentos do processo histórico que levou a independência politica do Brasil". (COTRIM, Gilberto. Op. Cit., p.223). A associação direta entre Inconfidência Mineira e a Independência era mais comumente feita em livros didáticos de décadas atrás. Um de Ensino Fundamental caracterizava a Revolta de Beckman, a Guerra dos Emboabas, a Revolta de Felipe dos Santos, a Guerra dos Mascates e as conjurações Mineira e Baiana como movimentos nos quais "os revoltosos se opuseram à metrópole, sonhando e lutando pela autonomia do país". ALVES, Kátia Corrêa Peixoto e GOMIDE, Regina Célia de Moura Belisário. Nas trilhas da história, Ensino Fundamental, Belo Horizonte, Dimensão, 1999, v.4). Citado por PURIFICAÇÃO, Ana Teresa da. Op. Cit., p.108.

73

FIGUEIRA, Divalte G. Op. Cit., p.191. Nos de Ensino Fundamental: AQUINO, Rubim de; LOPES, Oscar P. Campo; PIRES, Maria Emilia B. Op. Cit., p.100; CARM0, Sônia S. do; COUTO, Eliane F. B. A. A consolidação do capitalismo e o Brasil império. São Paulo: Atual, 1997 (História Passado Presente, 3), p.105; FERREIRA, José Roberto. História Edição Reformulada. São Paulo: FTD, 1997 (7ª série), p.65; ALVES, Kátia Correia Peixoto e GOMIDE, Regina Célia de Moura Belisário. 0p. Cit., p. 128. Citados por PURIFICAÇÃO, Ana Teresa da. Op. Cit., p.78, 84-85, 96 e 111.

74

Debret, Rugendas, Moreaux, Félix Taunay, Constantino Fontes, Pollière, Parreiras, Benedito Calixto, Delerive, Martins Viana, Oscar Pereira da Silva, Georgina de Albuquerque e Aldemir Martins, entre outros.

75

Isso já era frequente há uma década com livros de Ensino Fundamental, como por exemplo: ALVES, Kátia Corrêa Peixoto e GOMIDE, Regina Célia de Moura Belisário. Op. Cit., p.126; e COTRIM, Geraldo. Op. Cit., p. 112; conforme análise de PURIFICAÇÃO, Ana Teresa da. Op. Cit. p.113 e 123. Há que se dizer que livros didáticos não são meio exclusivo para esse esvaziamento do valor documental da iconografia, havendo na própria publicação acadêmica problema semelhante, como demonstra CAVENAGHI, Airton José. 0 atlas do império do Brazil e as representações presentes no livro. Projeto História, v. 41, 2010, p. 383-403.

76

Constatação semelhante à de PURIFICAÇÃO, Ana Teresa da. Op. Cit., para os didáticos de Ensino Fundamental.

77

NOGUEIRA, Fausto e CAPELLARI, Marcos. 0p. Cit., p.255.

78

Para um deles, "o pintor Pedro Américo imaginou a cena ocorrida às margens do riacho do Ipiranga" (AQUINO, Rubim de; LOPES, Oscar P. Campo; PIRES, Maria Emília B. Op. Cit., p.100; para outro, um célebre quadro mostraria uma "cena de uma do tópico que seja decorrente de debates acadêmicos. No entanto, ainda é frequente que tais conteúdos se inclinem à pura formalidade, dificilmente explicitando divergências oriundas da academia ou resultando em uma tomada de posição realmente crítica perante a história. ${ }^{69}$ Ao usuário do livro é apresentada uma suposta pluralidade de pensamento, não como ferramenta de obtenção dessa pluralidade, mas como estilo de composição e padronização do material didático. ${ }^{70}$

Esse tipo de atitude formalista pode ser encontrada também em propostas de atividades dirigidas ao aluno, como esta:

A interpretação sobre a independência do Brasil provocou e ainda provoca muitas divergências. Sob o ponto de vista econômico, alguns pesquisadores defendem que a separação ocorreu de fato em 1808 [...]. Outros, com interpretações mais políticas, indicam o 7 de setembro de 1822, embora nenhuma medida formal tenha sido tomada nessa data - foi um ato simbólico! Depois da Guerra do Paraguai, jornais republicanos argumentavam que [...] D. Pedro havia atendido aos apelos de independência dos brasileiros, mas os teria traido quando fechou a Assembleia Constituinte em 1823. Enalteciam, então, a Inconfidência Mineira (1789), a Revolução Pernambucana (1817) e a Confederação do Equador (1824), movimentos com teor republicano, conforme as reais aspirações dos brasileiros.

São várias interpretações, que variam de acordo com a posição política ou momento histórico dos autores. Alguns intelectuais consideram até mesmo que o Brasil, hoje, tem uma independência mais nominal do que real, pois continuaria dependente dos paises mais ricos.

Em sua opinião, quando o Brasil se tornou um país independente? ${ }^{71}$

Aqui, novamente, é apresentada uma divergência de interpretação, e várias são as possibilidades de resposta à pergunta: quando o Brasil se tornou um país independente? No entanto, todas as posições apresentadas parecem equivaler-se, pois tudo depende da "posição política" ou "do momento histórico" da pessoa disposta a respondê-la. Assim, e por indução, a Inconfidência Mineira poderia ser uma resposta aceitável, conforme visão ainda presente em alguns livros ${ }^{72}$ e a despeito do contrário que historiadores vêm afirmando nas últimas décadas. Do mesmo modo, a atividade pareceria aceitar a "não independência de fato", ideia muito presente na cultura de história no Brasil, ${ }^{73}$ tão sedutora quanto inconsistente do ponto de vista acadêmico. Para o aluno, tratar-se-ia de uma questão de simples opção (política?), diante da qual a História se destemporaliza.

Uma História processual, mais do que episódica ou personalista; uma História permeada de explicações acadêmicas; ao mesmo tempo, uma História com limitações em termos de divergências, relativizações e possibilidades em aberto, condicionada a suportes materiais repletos de convenções, a tornarem-nos muito parecidos entre si. Talvez seja no tratamento dispensado a imagens que os livros didáticos melhor revelam tais convenções, reforçando as limitações de seu diálogo com a História acadêmica, bem como acentuando suas características de mercadoria. Todos os livros aqui considerados são carregados de itens específicos a quebrarem a continuidade do texto, e suas páginas são multicoloridas e povoadas por figuras, como obras de pintores dos séculos XIX e XX. ${ }^{74}$ Quase nunca, porém, tais imagens são analisadas como fontes históricas, confinadas à função de mera ilustração, frequentemente modificadas em cor e tamanho, até mesmo mutiladas - sem esclarecimento - em prol da diagramação. ${ }^{75} \mathrm{Em}$ tais casos, inevitavelmente cria-se uma ideia não de uma história sujeita a múltiplas interpretações (contrapondo-se, portanto, a várias das atividades 
sessão das cortes de Lisboa, reconstituída pelo pintor Oscar Pereira da Silva". Cfr. CARMO, Sônia do; COUTO, Eliane F. B. A. Op. Cit., p. 73; um terceiro propunha ao aluno a seguinte atividade: "observe cuidadosamente as gravuras de Debret que aparecem no texto. Descreva cada uma delas e compare as cenas nelas retratadas com as cenas de nossas ruas de hoje. Há diferença? Em que sentido?". Cfr. GARCIA, Leônidas F. Estudos de história: sociedades contemporâneas. 2. ed. rev. Goiânia: Editora da UFG, 1996, Manual do Professor, p. 111. Todas as informações foram retiradas de PURIFICAÇÃO, Ana Teresa da. Op. Cit. p.81, 88 e 137.

79

Conforme bem mostrado por Elias Saliba. Cfr. SALIBA, Elias, Experiências e representações sociais: reflexões sobre o uso e o consumo das imagens. Anais do /l Encontro Perspectivas do Ensino de História. São Paulo: FEUSP, 1996; citado por PURIFICAÇÃO, Ana Teresa da. Op. Cit., p.119.

80

Produzida pela Secretaria de Ensino à Distância do Ministério da Educação, em parceria com a TV Escola e a Fundação Joaquim Nabuco, com a companhia teatral Mão Molenga. Parte 1 disponivel em youtube.com/ watch?v=Z60eHBJ1xjY, 18.082 visualizações e 15 comentários; parte 2 disponivel em youtube.com/ watch?v=20LkP2NDhMg, 30.100 visualizações, 8 comentários (parte desse episódio também disponivel em youtube.com/watch?v=bAPUjP7I-II, 18.398 visualizações e 16 comentários, acesso em $13 / 02 / 2014$.

81

Como Clemente Pereira, Gonçalves Ledo, Cipriano Barata, Paes de Andrade e frei Caneca. 0 fato de se tratar de uma produção pernambucana contribui para tanto.

82

Semelhante observação pode ser feita a respeito dos doze curtos episódios da série $D$. João no Brasil, inspirada em uma narrativa em quadrinhos da chegada da Corte ao Brasil, série de animação produzida pelo Canal Futura, baseada no livro de história em quadrinhos $D$. João Carioca: a corte portuguesa chega ao Brasil (1808 - 1821), escrito pela historiadora Lilia Schwarcz e pelo desenhista Spacca (São Paulo: Companhia das Letras, 2007). Novamente, tem-se um material convincente, afinado em muitos sentidos com um conhecimento acadêmico mas que, ao recorrer à sátira, também evoca estereótipos convencionais como, por exemplo, os mesmos acima mencionados em referência a príncipe e princesa Poder-se-ia atribuir tal convencionalismo, dentre outros fatores, ao de que a primazia da linguagem visual aqui opera duplamente; isto é, com os quadrinhos e também com o programa televisivo criado a partir deles, amplificando assim os efeitos decorrentes da saturação visual da sociedade que dá origem e significado a esse material. Para todos os efeitos, a imposição de tais convenções é forte até mesmo, conforme já visto, em materiais menos visuais que este. Episódio 01: youtube.com/watch?v= 9f5RB1zcD5ECtlist=PLyP1 ks9vaqhj2y6MmckU DyuXtWmHgPLe5Ctindex=1, 331 visualizações, nenhum comentário; episódio 02: youtube.com/watch?v= w-BLqvhYPGkCtlist=PL5837763F26AB1B87, oferecidas pelos próprios livros), mas de uma história imóvel a ser captada de modo instantâneo, uma história verdadeira. Além do mais, confundemse os diferentes contextos, motivações e condições de produção de tais imagens, o que equivale à oferta de uma confusão temporal que impossibilita a compreensão dessa história. ${ }^{76}$

As únicas exceções são os célebres quadros de Moreaux e de Pedro Américo. Todos os livros didáticos aqui considerados se esforçam por submetê-los a uma crítica, muitas vezes comparativa, considerando forma, conteúdo e contexto; mesmo assim, é possivel encontrar afirmações como a de que Américo teria tido "o intuito de fazer a representação desse famoso acontecimento da maneira mais fiel possivel", e que "muitos dos elementos representados pelo pintor são sabidamente falsos".77 Provavelmente, são resquícios de um momento anterior, no qual os livros didáticos mostravam-se muito menos cuidadosos até mesmo na utilização do quadro de Américo, ${ }^{78}$ mas também marcas atuais de uma sociedade de hábitos fortemente visuais, cuja saturação de imagens tende a resultar em posturas pouco críticas em relação ao que se vê, bem como em indistinção temporal das mesmas. ${ }^{79}$ Há que se lembrar, por fim e novamente, que os textos desses livros são cheios de descontinuidades, como se cada pedaço de cada página tivesse autonomia, prescindindo de certo modo da leitura dos demais. Guardarão tais constatações alguma relação com as dificuldades apresentadas pelos entrevistados na sondagem de opinião, de organizar visões da História da Independência segundo marcos cronológicos, bem como de distinguir diferenças entre intervalos temporais? É bem possivel; sobretudo porque ela será endossada pela observação de outras fontes.

\section{5 - A Independência na internet e na tevê}

Existe farto e rico material audiovisual disponivel na internet com referências à Independência do Brasil e que, a exemplo dos livros didáticos, representam a convergência de esforços profissionais múltiplos (mais os programas de tevê do que os vídeos independentes), como pesquisadores, roteiristas, apresentadores, repórteres, cenógrafos, técnicos variados, etc. As fontes aqui delimitadas perfazem 107 vídeos acessiveis no YouTube e que, não obstante sua amplíssima diversidade, convergem em muitos significados.

Observe-se o caso de vídeos educativos, documentários e programas de televisão com entrevistas e debates que, em comum, apresentam objetivos formativos e esforços verdadeiros de incorporação de conteúdos acadêmicos, traduzidos em linguagens didáticas. Um caso exemplar é a série 500 anos: 0 Brasil - Império na TV, que conta uma história do Brasil, da chegada da Corte ao período das regências, em formato de telejornal, com trama romanceada e teatro de bonecos. ${ }^{80}$ Aqui, vê-se uma História processual, com informações corretas e amparadas em datas, deslocamentos frequentes dos eixos espaciais de observação (regional, internacional), com menção a personagens que extrapolam o tradicional círculo da Corte portuguesa ${ }^{81}$ e ênfase no caráter violento e conflitivo da formação do Brasil no século XIX. Mesmo um material histórico-pedagógico desse quilate evoca, por exemplo, a falta de atributos estéticos de Carlota Joaquina ou a pusilanimidade de seu marido, a revelarem, mais uma vez, o mercadologicamente eficiente componente biográfico-anedótico no tratamento da Independência, advindo de sua inserção em uma cultura de história mais ampla. ${ }^{82}$

Em outros casos, o fato de programas de televisão buscarem o auxilio de especialistas na Independência revela uma convenção formal, como nos 
16.566 visualizações, 6 comentários; episódio 03: youtube.com/watch? $v=0 v W S E-s F-w 4 C t$ list =PL5837763F26AB1B87, 18406 visualizações, 8 comentários; episódio 04: youtube.com/watch?v= 2N5wBvpgyXECtlist=PL5837763F26AB1B87, 12.808 visualizações, 5 comentários; episódio 05: youtube.com/watch?v=VaHrSAFBf1UCtlist $=$ PL5837763F26AB1B87, 14.615 visualizações, 5 comentários; episódio 06: youtube.com/watch?v= 8RrCMb0ZTsACtlist=PL5837763F26AB1B87,

12649 visualizações, 10 comentários; episódio 07: youtube.com/watch?v=14cgWo_GHaO,

601 visualizações, 01 comentário; episódio 08: youtube.com/watch?v=rl71YNrLo7o, 12299 visualizações, 01 comentário; episódio 09: youtube.com/watch?v=huv2ngnqUd4, 367 visualizações, 02 comentários; episódio 10: youtube.com/watch?v=F2MaLs_kj-w, 10842 visualizações, 03 comentários; episódio 11: youtube.com/watch?v=8zK3D01dXc0, 9388 visualizações, 05 comentários; episódio 12: youtube.com/watch?v=R76BHD-vB8Ctlist=PL5837763F26AB1B87, 12108 visualizações, 9 comentários; acessos em 03/04/2014.

83

NAPOLITANO, Marcos, A História depois do papel. In: Carla Pinsky (org.) Fontes Históricas. São Paulo: Contexto, 2005, p.250-252. Napolitano afirma, com base em Umberto Eco, que a televisão introduziu uma mudança de ritmo de vida familiar e cotidiana, bem como o que se pode chamar de hipertrofia sensorial em detrimento da assimilação conceitual. Destaca, ainda, que é preciso pensar a televisão como uma nova experiência social do tempo histórico na medida em que ela faz coincidir o verdadeiro, o imaginário e o real no ponto indivisivel do presente.

84

Produzida pela rede de emissoras públicas TV Brasil. Sobre a Revolta dos Alfaiates, parte 1: youtube.com/watch? =vhiykcX3IKo, 767 visualizações, nenhum comentário; parte 2 : youtube.com/watch?v=dj04LJM8bk, 2592 visualizações, nenhum comentário. Sobre a Batalha do Jenipapo: parte 1: youtube.com/ watch? $v=z \operatorname{lgs} Z c j-V 30,2426$ visualizações, 02 comentários, acesso em 24/03/2013; parte 2: youtube.com/watch?v=rAS3dHAvWPQ, 1283 visualizações, 01 comentário. Sobre Tiradentes: youtube.com/watch?v=z50khMDrTTI, 408 visualizações, nenhum comentário (acessos em 24/03/2013).

85

Marco Morel e Luís Henrique Dias Tavares.

86

Programa De lá pra cá, Revolta dos Alfaiates, parte 1: youtube.com/watch?v=vhiykcX3IKo

87

Exceção são as entrevistas realizadas por Mônica Teixeira, na UnivespTV, que estabelecem comunicação bastante profícua entre a entrevistadora e os acadêmicos entrevistados (youtube.com/watch?v=syXf3WHQRPM, 4450 visualizações, 06 comentários; youtube.com/watch?v=pZk5pFlboqw, 3303 visualizações, 01 comentário;youtube.com/ watch?v=5pUDP2KUYCY, 4128 visualizações, 04 comentários: livros didáticos; e a exemplo destes, a intenção de acolher uma multiplicidade de vozes raramente enseja verdadeira pluralidade de pensamento, o que ademais é dificultado pela natureza curta, sintética e acelerada dos materiais televisivos. Nessas situações, constata-se que o historiador fala uma coisa, mas o entrevistador e o produtor continuam a "escutar" outra, o que muitas vezes reforça a percepção de descontinuidade narrativa, anteriormente também diagnosticada nos livros didáticos, e que na televisão adquire contornos de regra. ${ }^{83}$ Os episódios da série De lá para cá, educativos, didáticos, ávidos por com conhecimentos acadêmicos, e produzidos por uma rede pública de televisão sem fins lucrativos, apresentam interessante exemplo ${ }^{84}$. No programa dedicado aos acontecimentos de 1798 na Bahia, dois historiadores profissionais ${ }^{85}$ esclarecem que os revoltosos "bahienses" almejavam a independência apenas da capitania da Bahia, o que tem enormes implicações a destituírem tais acontecimentos de qualquer atributo supostamente preparatório da Independência do Brasil (situação muito semelhante, conforme vimos, à da Inconfidência Mineira); não obstante, na abertura do programa, seu apresentador declara:

A luta pela independência do Brasil foi escrita nas páginas memoráveis da nossa história, com o sangue de um punhado de brasileiros. 0 mais celebrado foi Tiradentes. Mas, sete anos depois do martírio de Tiradentes, quatro brasileiros, pretos, pobres, pelos mesmos ideais, foram enforcados e sentenciados em Salvador. ${ }^{86}$

Em outros momentos, o apresentador, apesar de ouvir de forma solícita e atenta ao que o entrevistado tem a dizer, acaba por negar, com sua própria fala, parte do conteúdo recém-ouvido, mas sem demonstrar ser essa atitude premeditada ou consciente. Afinal, é difícil desvencilhar-se daquilo que já se "sabe", daquilo que advém de um ambiente que, o tempo todo, nos "ensina" História sem necessariamente disso nos darmos conta. ${ }^{87}$

A incapacidade de assimilação reciproca de ideias acerca da história entre agentes sociais diversos pode revelar-se de muitos modos. Um dos programas da série Caminhos da Reportagem, intitulado Caminhos da Independência: o grito nas ruas, produzido com as mesmas características do anterior, aborda a Independência focada em seus panfletos políticos, a partir da pesquisa recente de três historiadores profissionais. ${ }^{88}$ No entanto, e a despeito não só de dar ampla voz a eles, mas também de abordar conteúdos didaticamente inovadores, a equipe de entrevista que foi às ruas não estabeleceu qualquer mediação entre histórias acadêmicas e não acadêmicas, pressupondo que todas as pessoas ocupam uma mesma posição em uma cultura de história. Por isso, perguntas incompreensiveis ${ }^{89}$ resultam apenas em situações vexatórias, impeditivas da construção de conhecimento sobre o tema.

A abordagem de pessoas nas ruas, recurso frequentemente utilizado por programas televisivos, revela dados importantes acerca de como os brasileiros veem a Independência, muitas vezes mais por aquilo que é perguntado do que por aquilo que é respondido. ${ }^{90} 0$ programa + Estilo de 07 de setembro de 2011, produzido pela TV Campo Grande, com conteúdo de variedades destinado a telespectadores de meio de tarde, foi às ruas (provavelmente de Campo Grande, Mato Grosso do Sul) perguntar se as pessoas saberiam dizer o que se comemorava naquele dia. Primeiro, responde uma jovem com um bebê no colo: 
youtube.com/watch?v=0ZVgCwkt1 ms, 1384 visualizações, 03 comentários; youtube.com/ watch?v=Va1Ern6GTsc, 1016 visualizações, 01 comentário;youtube.com/watch?v=Va1Ern6GTsc, 1227 visualizações, 03 comentários; youtube.com/watch?v=ANSHAFLau04, 1175 visualizações, 04 comentários). Acessos em 21/04/2014.

88

José Murilo de Carvalho, Lúcia Pereira das Neves e Marcello Basile.

89

A apresentadora: "Vocês sabem o que significa corcunda?" Um professor de colégio: "Deve ser alguma coisa que está surgindo aí no mundo um pouco mais cibernético porque eu nem na faculdade ouvi falar dos corcundas." Marcos Tomazzeti, produtor multimídia: "Na minha cabeça vem algo de monarquia, de rei, algo meio político." Simone Granda, bancária: "Dicionário de corcundice? Não sei!" Marilu Guimarães, dona de casa: "Puxa, tem tanta coisa importante pra ter dicionário, vai ter justo do corcundista?" Caminhos da Independência: youtube.com/ watch?v=37XH5UEpjll, acesso em 24/03/2013.

90

Em perspectiva oposta, mas complementar, à da sondagem de opinião aqui utilizada.

91

E que, portanto, muito provavelmente ainda não tinha tido contato formal (escolar) com o tema

92

0 programa prossegue, então, com uma entrevista com o professor lan Rari, que trata de uma História da Independência processual, não centrada em uma única data ou fato, crítica, etc. Mais um momento onde as várias vozes contempladas pelo programa não dialogam entre si (youtube.com/ watch? $v=x v 1$ LOIwUfFO, 289 visualizações, nenhum comentário). Outro exemplo significativo é dado pelo programa Conexão Jovem, exibido em 06 de setembro de 2012, no qual dois entrevistados - Prof. Bira, professor de História e Marcos Eduardo, sociólogo - utilizam com competência o pouco tempo a eles destinado, discorrendo de modo crítico sobre a Independência, e em linguagem adequada ao público jovem ao qual o programa se destina (produção da TV Novo Tempo, adventista: parte 1: youtube. com/watch?v=1lvYOYtju9s $>$, 74 visualizações, nenhum comentário; parte 2: youtube.com/ watch?v=0fv70WOJpHo, 47 visualizações, nenhum comentário (acessos em 24/03/2013). Logo, o programa traz uma abordagem feita na rua, na qual a entrevistadora pergunta a uma jovem: "Quem falou 'independência ou morte' às margens do riacho do Ipiranga?" Diante da correta resposta, a entrevistadora tenta induzir um erro: "15 de novembro, ou 7 de setembro?" Aliás, a expectativa do programa parece revelada pela entrevistadora logo na primeira pergunta feita a um dos convidados: "será que os jovens se interessam pela história de seu pais?". E embora o material recolhido pelo próprio programa permita resposta afirmativa, mantém-se a postura negativa, pré-concebida

93

Daí a relevância de um vídeo com fotografias e um áudio (youtube.com/watch?v=UdQ_aAAI3DE)
Pergunta: "Você sabe porque é feriado dia sete de setembro?" Resposta: "Independência do Brasil".

Pergunta: "E isso em que ano que foi que aconteceu?"

Resposta: "1822".

Em seguida outro jovem, que provavelmente já tinha respondido a outra pergunta:

Pergunta: "Quem foi o imperador, você lembra?"

Resposta: "D. Pedro I."

Pergunta: "Acertou. Canta pra gente um trecho do hino da independência?" Resposta: "Agora não lembro."

Agora, o programa aborda uma menina de cerca de dez anos, claramente intimada: ${ }^{91}$

Pergunta: Por que é feriado dia sete de setembro?"

Resposta: "Não sei".

Pergunta: "Não lembra? Vou dar uma dica: um fato histórico muito importante para o Brasil".

Resposta: (negativa com a cabeça).

Em quarto lugar, outra jovem, que procura se afastar da câmera:

Pergunta: "Você sabe porque é feriado dia sete de setembro?"

Resposta (ainda tentando se esquivar, sorrindo): "Não".

Pergunta: "Não sabe?"

Resposta: "Ah! A Independência. Eu não prestei atenção".

Pergunta: Que ano aconteceu a Independência, você lembra?"

Resposta: "Não".

Pergunta: "E quem foi o imperador?"

Resposta: "Também não lembro".

Por fim, a entrevista com um senhor de meia-idade começa já com uma resposta:

Resposta: "Independência do Brasil".

Pergunta: "Que ano aconteceu isso?"

Resposta:"1888".

Pergunta:"1822. Quem foi o imperador?"

Resposta: "D. Pedro I".

Pergunta: "Certo. E onde foi que aconteceu tudo isso?"

Resposta: "São Paulo".

Pergunta: "OK... [breve silêncio] Canta um trechinho para nós do hino da Independência?"

Resposta: "Já podeis da pátria mãe" [sic -prossegue cantando corretamente].

Em seguida, o programa corta para uma sala de aula onde, a despeito dos "acertos" obtidos nas ruas, a entrevistadora afirma:

Diante da dificuldade que nós encontramos no centro da cidade para saber informações sobre a Independência do Brasil, eu vim parar na sala de aula. Vai ser aqui que a gente vai descobrir a história do pais. $^{92}$

A ideia a priori de que o brasileiro não conhece e não se interessa pela história subsidia este e muitos outros programas. Aqui, o dado mais relevante parece estar precisamente nessa arraigada crença no desinteres- 
da então prefeita de Ribeirão Preto (São Paulo), Darcy Vera, que afirma, durante um desfile de 7 de Setembro, dentre vários desvarios, que "Tiradentes gritou 'Independência ou morte'". Com 169.919 acessos e 149 comentários (em geral críticos, bem humorados e depreciativos) até 20/08/2014, condensa a possibilidade de amplificação do estigma do não domínio de referências convencionais à Independência, mas sem fomentar nenhum conhecimento da mesma.

94

Novamente, surge a questão: não terão as renovações curriculares promovidas no ensino de História (no Brasil e alhures) das últimas décadas exagerado nessa incompatibilidade? Terão elas sido capazes de mensurar seus efeitos deletérios diante de sociedades já bastante refratárias a uma história cronológica?

95

"Pouco importa que sua figura tenha sido mitificada pela propaganda republicana. 0 que importa é que ele foi um herói. Ele deu sua vida pela pátria e pela liberdade" (Programa De lá pra cá: youtube.com/watch?v=z50khMDrTI, 360 visualizações, nenhum comentário, acesso em 26/03/2013). Essa exaltação da figura de Tiradentes associada à Independência conduz o discurso da propaganda eleitoral de um candidato à prefeitura de Ouro Preto em 2012 (youtube.com/watch?v=eGefgLoRhec, 360 visualizações, nenhum comentário, acesso em 26/03/2014). Em entrevista ao programa Roda Viva da TV Cultura de São Paulo, no dia 09 de setembro de 2013, após se autocaracterizar como realizador de uma "história de carne e osso" em contraposição a produções "contaminadas pela análise marxista" que retirariam os personagens da História, o jornalista Laurentino Gomes afirma: "No 1822 faço uma comparação, e digo que o único problema do José Bonifácio foi nascer no Brasil, pois se ele tivesse nascido nos Estados Unidos teria sido maior que o Thomas Jefferson. Porque aparentemente ele era mais preparado, mais lúcido que o Thomas Jefferson" (parte 1: youtube.com/watch?v=uGibbLxsZK0, 4501 visualizações e 5 comentários; parte 2: youtube. com/watch?v=2LQcEcb5kLU, 2302 visualizações, 6 comentários, acesso em 26/03/2014. Logo voltaremos à obra e às ideias de L. Gomes.

96

Um exemplo advém do vídeo "A verdadeira independência do Brasil", em que um pastor evangélico, em meio a uma cerimônia religiosa, "desconstrói" o quadro de Pedro Américo, acusando-o de pouco verossímil, e aponta os desvios morais de $D$. Pedro I de modo a inviabilizá-lo como figura histórica digna de memória (youtube.com/watch?v=RsKOr6bgzLA, 178 visualizações e 2 comentários, acesso em 24/03/2014). A suposta irrelevância dos personagens envolvidos no processo da independência é notável na fala de um professor de Ensino Médio (youtube.com/ watch?v=gvWVF9j2KEU, 597 visualizações e nenhum comentário, acesso em 24/03/2014) e de um apresentador de temas religiosos, que relativizam a importância do tema ao afirmarem a atual "dependência econômica" do Brasil (youtube.com/watch?v=EXyUBY7StF4, 383 visualizações e nenhum comentário, acesso em 24/03/2014). Também retornaremos a esse tema. se/desconhecimento do brasileiro pela história, bem como em um de seus efeitos mais contundentes: a crença de que é possivel reverter tal situação pela simples mobilização formal de datas, nomes e eventos. Contudo, se a Independência se converte em uma catalizadora de referências cronológicas ou nominais, isso não leva necessariamente a uma historicização do tema; pelo contrário, a mobilização de tais referências em termos como os acima mencionados (a data ou o nome por si sós) pode resultar no aprofundamento da tendência à confusão temporal já aqui apontada. ${ }^{93}$

Nos meios intelectuais, a discussão em torno das formas temporais de vivência coletiva naquilo que se pode chamar - recorrendo-se a uma categoria útil - de modernidade não é nova, tampouco está em vias de esgotamento. A dificuldade de organização do mundo social segundo referências cronológicas não será, em absoluto, distintiva de uma cultura de história no Brasil, embora o contrário deva ser dito em relação às formas assumidas por tais dificuldades (como as noções, concepções e representações da Independência). Percebe-se, então, o peso do estigma da dificuldade em manejar datas, nomes e fatos, suposta prova de um desinteresse/ignorância que poderia ser combatido com um retorno a velhas formas de se fazer História, e nas quais tais elementos eram considerados com a essência da compreensão histórica. Não parece que as coisas devam propriamente se passar segundo essa representação, embora um dos confrontos existentes na cultura de história no Brasil seja, sem dúvida, a polarização entre a valorização da Independência (= de suas datas, nomes, eventos, símbolos e supostos valores, etc.) e a desvalorização da mesma (=seu caráter elitista e negociador, a diminuição da história do Brasil em comparação com a de outros paises, a comicidade dessa história, etc.). É plausivel conceber que esta segunda posição encontre um aliado na concepção de incompatibilidade entre uma história amparada por referências cronológicas e, ao mesmo tempo, em processos, estruturas e temas transversais, do gosto, inclusive, de muitos acadêmicos e educadores. ${ }^{94}$

Os exemplos de materiais audiovisuais a traduzirem, veicularem e fomentarem esse confronto entre valorização e desvalorização da Independência são muitos. Além dos já tratados até aqui, pode-se mencionar vídeos contendo propaganda de instituições públicas civis e militares, de partidos políticos, de grupos maçônicos, de igrejas e de empresas variadas, bem como produções independentes. Neles, é possivel encontrar desde a exaltação das referências mais convencionais à Independência, como a seus personagens (incluindo seu suposto mártir, Tiradentes) ${ }^{95}$ até a afirmação de sua total irrelevância; ${ }^{96}$ isso costuma ocorrer sem muitos matizes, obedecendo a uma lógica dicotômica plasmada em linguagens simples, com descontinuidades discursivas e imagéticas, e num ritmo de exposição acelerado. Em suma: tratam da Independência segundo padrões parcialmente compartilhados também por outras fontes até aqui analisadas.

Todas essas fontes, com suas noções, concepções e representações da Independência, são sintomáticas de estados de espírito dos brasileiros em torno do tema, bem como potenciais formadores de opinião dos mesmos. Sua capacidade de criação de conhecimento, no entanto, se mostra muito limitada. É bem verdade que esta é, por vocação, uma tarefa confiada a saberes acadêmicos - já que, no Brasil, a quase totalidade da pesquisa em História está entregue às universidades, salvo a de interesse corporativo - de modo que não seria de esperar inovação em suportes tão variados e socialmente diversificados quanto os até aqui analisados. Mas parece haver aí certo 
Exemplo encontra-se no vídeo "Away Nilzer Independência do Brasil", com grande número de visualizações (130.677) e de comentários (1016), que minimiza e ridiculariza não apenas o processo da independência, como quaisquer fatos históricos brasileiros de maneira geral (youtube.com/watch?v=Vd_kloNeQV0). 0 Brasil atual, como vitima de uma exploração econômica mais intensa do que nos tempos coloniais e, portanto, não-independente, aparece na fala de outro professor (youtube. $\mathrm{com} /$ watch? $\mathrm{v}=\mathrm{cFHySuce} 9 \mathrm{Tw}$ \&tplaynext $=1$ \&tlist= PL60A27756B33DE105\&feature=results_main, 2806 visualizações, 8 comentários) e nos comentários de um boneco marionete de um programa infantil (youtube.com/ watch?v=9mh3Tu6c4_w, 173 visualizações, nenhum comentário (acessos em 24/03/2014).

98

Exemplo desse processo de "devolução" pode ser comprovado no vídeo "Independência ou morte" (youtube.com/watch?v=QUvnz $1 \mathrm{no} 1 \mathrm{~m} 8,934$ visualizações e nenhum comentário, acesso em 24/03/2014). Outros dois exemplos pertinentes são a insistência nas ideias de que as Cortes de Lisboa queriam recolonizar o Brasil, e que a Independência foi uma luta entre brasileiros e portugueses.

99

Em entrevista a uma rede local de televisão, ouvimos do professor de história do Ensino Médio Wander Pugliesi: "Se nós formos trabalhar com sinceridade o Brasil ainda não é independente. $\mathrm{Na}$ verdade somos muito mais explorados do que quando éramos colônia de Portugal" (youtube. com/watch?v=cFHySuce9Tw\&tplaynext=1\&list= PL60A27756B33DE105\&feature=results_main, 2815 visualizações, 8 comentários). A mesma relativização do processo de independência aparece na fala do candidato à presidência em 2010 pelo PSTU, Zé Maria: "hoje, infelizmente, não podemos comemorar uma verdadeira independência do pais. É preciso dizer a verdade: as multinacionais controlam a economia brasileira. As decisões fundamentais são tomadas por elas fora do pais" (youtube.com/ watch?v=ht9YtOPIGnU, 1803 visualizações, um comentário). Acessos em 26/03/2013.

\section{0}

Direção de Carlos Henrique Schroder, 2008. Produção de 16 episódios de cerca de 20 minutos cada para o canal da TV fechada GloboNews. A série foi comercializada em DVD e pode ser vista também no canal Globosat no Youtube (youtube. $\mathrm{com} /$ watch?feature $=$ player_detailpage $\mathrm{C} \mathrm{v}=$ OUX-zSyaMlc e vídeos relacionados. Acesso em 27/03/2014).

101

Direção de Wolf Maya e Alexandre Avancini, e criação de Carlos Lombardi, 2002. Produção de 48 episódios com cerca de 40 minutos cada para o canal da TV aberta Rede Globo de Televisão. A minissérie também foi comercializada em DVD e vem sendo (desde janeiro de 2014) reprisada no Canal Viva (rede fechada de televisão, filiada Globosat); uma reprise anterior ocorreu de agosto a novembro de 2011 , sempre por volta das $23 \mathrm{~h}$.

\section{2}

Direção de João Carrascosa e Pedro Bial, 2007. Produção de 9 capitulos de cerca de 15 minutos círculo vicioso, a envolver também parte da academia. Basta observar que a ideia da "não Independência de fato", tão em voga entre tantos historiadores durante tanto tempo, reverbera com força na sociedade em geral ${ }^{97}$ e ainda goza de prestígio até mesmo entre alguns acadêmicos, que bebem-na da sociedade e, após modificá-la parcialmente, devolvem-na aos espaços de divulgação. ${ }^{98}$ Essa versão da História é capaz de transpor fronteiras temporais, de atualizar-se em diferentes contextos, e até mesmo de superar abissais diferenças políticas: ela está representada, por exemplo, e de modo quase idêntico, na propaganda política de um partido trotskista e na pregação nacionalista-direitista de um polêmico professor de história. ${ }^{99}$

Por fim, tome-se o caso de três produções da Rede Globo de Televisão, voltadas ao público em geral, com consideráveis aportes financeiros e complexa produção: a série documental $A$ Corte no Brasil, para exibição em tevê fechada; ${ }^{100}$ e as séries humoristicas 0 Quinto dos Infernos ${ }^{101}$, e É muita História: Dia de Fúria, ${ }^{102}$ veiculadas amplamente em tevê aberta. No primeiro caso, sítios históricos visitados pelas apresentadoras, uma narrativa sóbria e informativa de fatos e processos, grande quantidade de entrevistas com historiadores, ênfase em diferentes espaços regionais e internacionais, e tratamento do tema em múltiplas dimensões (política, econômica, cultural). No segundo caso, uma narrativa, romanceada, teatral e cômica, fortemente despolitizada e livremente baseada em três livros de igual teor (um deles publicado há quase um século), ${ }^{103}$ praticamente centrada no Rio de Janeiro (um pouco também em Portugal, muito menos alhures) e nos membros da familia real portuguesa, cuja vida pessoal é estruturada em torno de seus hábitos excêntricos (principalmente os sexuais) e, vez ou outra, de passageiros dramas pessoais. ${ }^{104}$

Finalmente, no terceiro caso, uma encenação também cômica, protagonizada por um escritor-autor-ator-palhaço, com grande liberdade de criação, mas amparada em informações, convenções e mitos a oferecer uma versão do Sete de Setembro segundo o estado psico-fisiológico de D. Pedro.

Eis um exemplo de uma das modalidades assumidas pela disputa em torno de uma Independência valorizada e outra depreciada. Pareceria justificável opor a tal diagnóstico a constatação de se tratarem de obras televisivas de distinto teor, o que desobriga a segunda e a terceira de qualquer compromisso com a verdade. No entanto, interessam-nos mais seus significados e efeitos do que intenções. Note-se que a primeira, documental, é de circulação mais restrita que a segunda e a terceira, voltadas para grande público; por isso, seus efeitos nesse jogo de criação/recriação de noções, concepções e representações em torno da Independência são não apenas assimétricos, mas também concorrentes. ${ }^{105}$ Os esforços de um programa por posicionar o espectador diante de uma história processual, de encadeamentos temporais e de grupos e conflitos sociais, são naturalmente obstados pelos dos outros dois, a oferecer uma história repleta de anacronismos, anedótica e biográfica, em perfeita sintonia com demandas mais amplas de uma sociedade - e de alguns de seus componentes mercadológicos já aqui mencionados - na qual a vida privada é mais valorizada do que a pública. ${ }^{106}$ Nesse confronto, embora as três convivam na mesma cultura de história, uma Independência tende a prevalecer sobre a outra. ${ }^{107}$

\section{6 - A Independência no cinema}

Em relação a livros didáticos, programas de televisão e outros materiais audiovisuais, as fontes cinematográficas aqui consideradas naturalmente 
cada, dentro do programa dominical Fantástico da Rede Globo de Televisão. A série foi baseada no livro Brasil: uma História de Eduardo Bueno, jornalista que também atua na série (youtube. com/watch? $v=3$ LzGKt9PdOM, acesso em 27/03/2014)

103

SETÚBAL, Paulo. As Maluquices do Imperador. São Paulo: Companhia Editora Nacional, 1927; CALADO, Ivanir. A Imperatriz no Fim do Mundo: memórias dúbias de Amélia de Leichtenberg. Rio de Janeiro: Rio Fundo Editora, 1992; e TORERO José Roberto. Galantes memórias e admiráveis aventuras do virtuoso conselheiro Gomes, o Chalaça. São Paulo: Companhia das Letras, 1994

\section{4}

A trama e a narrativa do Quinto dos Infernos recusam explicitamente a inserção de quaisquer componentes que não os da ordem privada de seus convencionais personagens: assim, questões politicas são sempre menores do que o apetite sexual de Carlota Joaquina, as perversões de D. Miguel ou a fogosidade de Domitila; a economia só surge em pontuais pretextos cômicos, enquanto a escravidão é referida exclusivamente por meio de alegres e libidinosas criadas (negras) permanentemente dispostas a servirem aos desejos do herói da história, D. Pedro.

105

A análise poderia se completar com a minissérie A Marquesa de Santos, dirigida por Ary Coslov e exibida pela extinta Rede Manchete de televisão em 1984, à qual, infelizmente, não se obteve acesso satisfatório.

106

Tal predileção pode ser entendida como mais um fator caracteristico de um momento em que a articulação entre aquilo que Guy Debord chamaria de "sociedade do espetáculo", e Adorno e Horkheimer (dentre muitos outros) de "indústria cultural" torna sintomático a saliência do indivíduo e o esvaziamento da esfera pública.

107

A comprovação do encontro concorrente entre dois caminhos vem do depoimento de alguns dos próprios envolvidos com a produção do Quinto dos Infernos, como o diretor Carlos Lombardi, que a ele se refere como "um painel dos personagens importantes do periodo". Para o produtor Wolf Maia, seu objetivo foi "recontar, com humor, uma velha história". 0 ator Humberto Martins viu a série "contar um pedaço da nossa história, da história do Brasil, do nosso povo, das nossas raizes, patética e engraçada tal como ela se mostra dentro desse produto, porém, claro, mesclada com uma boa dose de humor", enquanto o protagonista Marcos Pasquim afirmou que "[ao fazê-la] aprendi muita coisa que não aprendi na escola, eu vim aprender agora fazendo a pesquisa para fazer esse personagem". Finalmente, para a também atriz Bruna Lombardi, "O 'Quinto' contou, assim, a história que a História não conta, sabe como é, as fraquezas da história". Em "Dia de Fúria", Pedro Bial e Eduardo Bueno reforçam seu discurso satírico por meio de um verniz de verdade trazido pela citação de documentos oficiais como o relato do Padre Belchior sobre o grito do Ipiranga. Além disso, seu discurso é elaborado sob o nome de tese; logo, bem se vê como seus propaladores (Bial/Bueno) manipulam símbolos apresentam especificidades. Tendem a diversificar (eventualmente ampliar) o rol de profissionais envolvidos em sua produção e veiculação, bem como a tratar conteúdos em um tempo mais lento, criando uma sensação de homogeneidade de significados reforçada pela aderência de tais conteúdos a uma trama central. Tal homogeneidade, por seu turno, é relativizada por uma liberdade de criação que dificilmente encontra paralelo em outros dos materiais aqui considerados - com a possivel exceção da minissérie 0 Quinto dos Infernos. No entanto, quando a comparação é feita com os livros didáticos, os conteúdos relativos à Independência, no cinema, tendem a ser menos numerosos, mais superficiais e efêmeros, justamente por serem menos assumidamente informativos do que os dos livros, embora isso possa encontrar alguma compensação em uma linguagem visual de forte apelo emotivo. Para todos os efeitos, como aponta um estudioso da matéria, os filmes de temática histórica carregam sempre certa ambiguidade, ocupam uma espécie de "entrelugar" com força para criar "verdades" socialmente aceitas. ${ }^{108}$ Nos cinco filmes aqui considerados, ${ }^{109}$ as "verdades" sobre a Independência tendem a replicar linhas de força já conhecidas, mesclando temporalidades correspondentes tanto aos momentos em que foram produzidos, quanto aos momentos posteriores em que foram sendo exibidos. ${ }^{110}$

Independência ou Morte, produção a serviço das comemorações oficiais do sesquicentenário da Independência levadas a cabo pelo governo ditatorial brasileiro em 1972, mostra uma narrativa de forte teor didático-pedagógico, sem grandes pretensões artísticas explícitas, ${ }^{111} \mathrm{com}$ diálogos e situações muitas vezes retirados de obras sobre a Independência e tratados de forma literal. Sua finalidade é clara: "ensinar" aos espectadores uma história e uma memória coletivas, homogêneas, aplainadas de pluralidades ou de desavenças. Uma história supostamente indiscutivel porque verdadeira, posta a serviço dos também supostos interesses mais elevados da nação brasileira (por isso, nela, a vida privada dos personagens é toda submetida à sua função política, inclusive no caso da relação afetiva entre um D. Pedro de boa aparência, querido do povo e mulherengo, e uma ambiciosa, romântica e sensivel Domitila ${ }^{112}$ ). Uma espécie de cartilha oficial da Independência em imagens, na qual se faz presente até mesmo uma recomposição cênica do quadro de Pedro Américo.

É interessante observar como Os Inconfidentes, produzido no mesmo ano de 1972, mesmo sendo um filme amparado em abundantes liberdades e experimentos estéticos, cheio de ambiguidades propositais e contrapondo-se ao oficialismo histórico tão em voga à época por meio de uma metáfora na qual os contestadores à ditadura brasileira se convertem em sediciosos das Minas Gerais do século XVIII, não se configura como material singular e discrepante de Independência ou Morte em, pelo menos, três sentidos: primeiro, porque em vários momentos associa a Inconfidência $\mathrm{Mi}-$ neira com a Independência do Brasil, a exemplo do que Independência ou Morte prega já em seu primeiro texto didático. ${ }^{113}$ Segundo, porque também oficializa eventos convencionalmente tidos por fundacionais da história do Brasil (só que não os de 1808-1822, mas os de 1788-1789). Terceiro, reforça a prevalência de indivíduos sobre coletividades, da imagem de um herói central da trama, e de uma oposição de interesses maniqueista que certamente poderia se aplicar com mais rigor ao contexto em que foi feito o filme do que àquele ao qual formalmente se refere. Assim, para todos os efeitos, substratos de uma concepção de história são em ambos convergentes. Em um ambiente social multifacetado em termos de no- 
de autoridade que não estão confinados à sátira (embora a dupla, na última cena do episódio, afirme que cada um conta uma história).

108

NAPOLITANO, Marcos. Op. Cit., p.236 e 237.

109

Independência ou Morte (1972), direção de Carlos Coimbra; Os Inconfidentes (1972), direção de Joaquim Pedro de Andrade; Tiradentes, o mártir da independência (1977), direção de Geraldo Vietri; Carlota Joaquina princesa do Brasil (1995), direção de Carla Camurati; e Tiradentes (1999) direção de Oswaldo Caldeira. Infelizmente o tardio acesso ao curta-metragem 0 corneteiro Lopes (direção de Lázaro Faria, 2009), não permitiu sua incorporação nessa análise.

110

Continuam a sê-lo, disponiveis em locadoras, em pacotes de filmes de TV a cabo, e em sítios da internet como o YouTube.

111

Exceção à sua primeira cena, que representa a dramaticidade da Abdicação: de início, vê-se as botas de um Imperador caminhante, solene e pensativo, cuja tomada de decisão logo conduz o espectador a uma narrativa retrospectiva, a durar todo o restante do filme.

112

Note-se quão pouco originais são os personagens de 0 Quinto dos Infernos, a despeito da impressão contrária que seu estilo cômico pode criar (na mesma direção poder-se-ia evocar a histérica Carlota Joaquina, que odeia o Brasil ou o sério José Bonifácio ao qual D. Pedro pouco dá ouvidos). Já uma discrepância absoluta se dá em relação a Leopoldina: mulher bonita, forte e politicamente consciente no filme; feiosa, ingênua e descartável na minissérie.

113

No qual se lê: "D. Pedro I tinha, então, nove anos. 0 seu testemunho de tão tumultuados acontecimentos, somado à carência de educação palaciana, por certo, marcaram o seu temperamento de homem de reações imprevisíveis. Daí a aceleração do processo da independência do Brasil, que teve suas raizes na Inconfidência Mineira". Além dessa clara associação entre a Inconfidência Mineira e a Independência, durante o filme Os Inconfidentes são dados elementos sutis que corroboram com a mesma posição, inclusive a fim de associar os inconfidentes "libertadores do Brasil" à resistência de esquerda, também imbuída da intenção de libertar o Brasil da ditadura militar. Cinco anos depois, Tiradentes, o mártir da independência, traria essa associação explícita no título, em favor da construção de um herói nacional perfeito, por meio de um enredo melodramático.

114

A Carlota ninfomaniaca, feia, ardilosa e má; a dúvida sobre Pedro - um amante irascivel - ser filho do medroso e comedor de frangos João, etc. Há que se lembrar que Carlota Joaquina é anterior ao Quinto dos infernos, sendo então o vetor de oferta e acúmulo de clichês daquele para este, e não o contrário. Sobre o filme, a ótima contribuição de Patrícia Cardoso. CARDOSO, Patricia da Silva. Op. Cit., p.35-44. ções, concepções e representações em torno da história, Independência ou Morte e Os Inconfidentes revelam-se em parte aliados, corresponsáveis pela manutenção de alguns traços que ainda são caracteristicos da inserção da Independência em uma cultura de história quarenta anos depois.

Bem se vê que a crítica à mensagem de um filme histórico por outro filme histórico não significa, necessariamente, a veiculação de uma História crítica. Carlota Joaquina é mais um exemplo disso, na medida em que sua versão irreverente da História do Brasil de começos do século XIX pode dar uma primeira impressão de implodir com aquela oferecida pelo oficioso Independência ou Morte; aqui, poder-se-ia falar mesmo em certo pioneirismo em termos de representações cinematográficas sobre a época. No entanto, a sátira e o deboche se fazem acompanhar de tamanha mobilização de componentes convencionais e mitológicos, ${ }_{1}^{114}$ anteriormente elaborados e fartamente disponiveis em muitos suportes, que a aparência de crítica logo se desvanece, cedendo lugar a mais um conjunto de representações indicativas do confronto entre uma Independência valorizada e outra depreciada, uma tão velha quanto a outra. As "verdades" aqui produzidas emergem de pelo menos dois elementos do filme: uma trama narrada por um professor que a "ensina", como história, a uma aluna criança (que logo se coloca no lugar da personagem principal), ambos aparentemente britânicos; e a afirmação do narrador de que "História é assim: quanto mais você lê, menos você conhece", ${ }^{115}$ ambos submetidos aos padrões de uma cultura de história já bem estabelecida e pouco modificada por um filme que teve circulação pública bastante considerável.

A observação desses filmes parece induzir à constatação de que, dentre os suportes materiais até aqui analisados, o cinema (aliás, consumido regularmente por 58\% dos entrevistados na sondagem de opinião, acima referida), sendo o mais criativo de todos, é também o mais pobre em termos de capacidade de oferta de conhecimentos inovadores sobre a Independência do Brasil. Embora deva se considerar que o escopo da pesquisa incluiu apenas cinco filmes, ${ }^{116}$ essa constatação ganha força diante de um aspecto mercadológico da produção cinematográfica no Brasil - cujas caracteristicas específicas não poderão ser aqui devidamente apreciadas - que imprime suas marcas sobre uma produção artística que precisa necessariamente, segundo sua lógica, ser vendida. Igualmente, deve-se ter em conta que a produção cinematográfica dialoga diretamente com as outras analisadas, ${ }^{117}$ também em geral pouco inovadoras, com elas estabelecendo um ciclo de determinações reciprocas.

\section{7 - A Independência nas livrarias e nas bancas de jornal}

A Independência do Brasil conhece ainda muitos e variados tratamentos em livros de divulgação histórica, em obras de ficção e poesia, em textos de complemento didático, e em outros que, ao tentarem mesclar um pouco de tudo isso, são de difícil classificação. Para esta pesquisa, observou-se o critério de elaboração e produção de acordo com os objetivos de consumo por parte de um público amplo, não restrito a estudantes e profissionais da História; com sua linguagem correspondente simples; e com sua inserção em um mercado educacional e cultural que enseja estratégias de produção, circulação e legitimação próprias. Em meio a tudo isso, é possivel encontrar enormes discrepâncias de conteúdo, com suas correspondentes - e nada fortuitas - discrepâncias também em termos de distribuição e aceitação social, bem como de peso de suas "verdades" no posicionamento da Independência em uma cultura de história no Brasil. 
115

0 sentido de tal afirmação parece propositadamente ambíguo: indica uma concepção de que a História está em permanente construção e é aberta, ou de que a História vem sendo contada de modo equivocado e que ela agora será devidamente relevada? Ambas as coisas?

\section{6}

Tiradentes, de 1999, não traz referências à Independência.

117

Vimos anteriormente como livros didáticos se voltam a filmes como Independência ou Morte! Os Inconfidentes e Carlota Joaquina. Também programas televisivos variados contém cenas de tais filmes que, por seu turno, amparam-se em pesquisas históricas que fatalmente os leva em direção a tais suportes, nos quais as elaborações acadêmicas nunca estiveram ausentes.

118

Poder-se-ia aumentar tal relação, pelo menos, com a inclusão do livro de Ruy Castro aqui não contemplado, mas analisado preliminarmente por Jorge F. Silveira. CASTRO, Ruy. Era no tempo do rei: um romance da chegada da Corte. Rio de Janeiro: Objetiva, 2007; SILVEIRA, Jorge Fernandes da. Retratos da Família Imperial no Brasil. In: OLIVEIRA, Paulo da Mota (Org.). Op. Cit., p.17-24. Provavelmente, a primeira obra literária significativa a ter a transferência da Corte para o Brasil como pano de fundo foi a de Manuel Antonio de Almeida. Memórias de um sargento de milícias, editada em folhetins entre 1852 e 1853.

\section{9}

Optamos por trabalhar com a segunda e ampliada edição, por trazer novos textos e novos personagens em relação à versão anterior, publicada em 2009. Os conteúdos mais diretamente ligados à Independência, por exemplo, e dessa maneira, fundamentais para este trabalho, se encontram nesta segunda edição. NARLOCH, Leandro. Guia politicamente incorreto da História do Brasil. 2a. ed. Rio de Janeiro: Leya, 2011.

120

0 secretário pessoal de D. Pedro viraria personagem de uma história em quadrinhos poucos anos depois: DINIZ, André e EDER, Antonio. Chalaça, o amigo do imperador. São Paulo: Conrad, 2005.

121

A máxima extensão permitida a esse círculo é em direção a outros personagens da Corte, como Francisco Rufino Lobato, que segundo Laurentino Gomes pode ter sido, ao mesmo tempo, amante da esposa de D. João, amante gay deste, e pai biológico de D. Pedro. GOMES, Laurentino. 1822: como um homem sábio, uma princesa triste e um escocês louco por dinheiro ajudaram D. Pedro a criar o Brasil - um país que tinha tudo para dar errado. Rio de Janeiro: Nova Fronteira, 2010, p.121.

122

SETÚBAL, Paulo. Op. Cit. A marquesa de Santos. São Paulo: Companhia GráficoEditora Monteiro Lobato, 1925. Acrescentar, em perspectiva muito diferente, Otávio Tarquínio de Souza e, antes dele, várias biografias de Pedro I e de outros personagens da Corte.
Observemos, de início, cinco obras significativas: ${ }^{118}$ O Chalaça (1994), de José Roberto Torero; 1808 (2007) e 1822 (2010), de Laurentino Gomes; Guia politicamente incorreto da História do Brasil (2011'19), de Leandro Narloch; e A carne e o sangue, de Mary Del Priore (2012). Para além de aspectos estilisticos e mercadológicos, tais obras convergem em muitos outros. Convergem, em primeiro lugar, por conferirem uma prioridade absoluta a personagens em seus enredos e concepções de história: um protagonistanarrador que, em tom de confissão, conduz os leitores por segredos supostamente não-desvendados do passado (Chalaça) ${ }^{120}$; uma família real povoada dos mesmos personagens excêntricos e caricatos de sempre (1808 e $\left.1822^{121}\right)$; supostos heróis e anti-heróis trocando de papéis constantemente (Guia); finalmente, tórridos amantes aristocratas cuja intimidade amorosa e sexual continua a ser visitada ( $A$ carne e o sangue). Em todos esses casos, a leitura induz à convicção de que, se a História não se faz apenas por personagens tão convencionais como esses, a deles deve ser a mais interessante, já que outras alternativas quase nunca são oferecidas.

A ênfase em personagens é antiga, como nos mostram as obras de Paulo Setúbal, de notável prestígio dentre divulgadores atuais de História. ${ }^{122}$ A "orelha" da recente reedição de um deles não poderia ser mais reveladora de uma concepção de uma História "verdadeira" a se revelar pelo bizarro, pelo pessoal e pelo divertido, de uma História contada como entretenimento, e da atualidade do tradicional sob a roupagem de inovação mercadológica:

Este livro começa com a estrepitosa chegada da Corte Portuguesa ao Brasil, em 1808, Dom João VI [sic] à frente, fugindo de Napoleão, com dona Maria, a Louca, a bordo. A história de como uma rainha louca, um príncipe medroso e uma corrupta enganaram Napoleão e mudaram a história de Portugal e do Brasil foi popularizada por Laurentino Gomes em seu extraordinário '1808'. [0 livro de Setúbal]. Começa no mesmo ano de 1808. A bordo de um dos navios que chegavam de Portugal estava um menino esperto de 10 anos, Dom Pedro, sucessor de Dom João VI [...]. Este menino haveria de crescer no Rio de Janeiro, meio largado, e são suas estripulias que Paulo Setúbal [...] relembra, com sua linguagem pitoresca e saborosa[...]. 0 rei glutão comedor de frangos, a feiura de Dona Carlota Joaquina, a corrupção dos barões e duques, a desenvoltura de um certo Chalaça, conselheiro do jovem Dom Pedro, as intrigas palacianas, os amores de Dom Pedro por atrizes e cantoras, seus gastos perdulários, tudo isso Setúbal nos revela como se roteirizasse um filme [...]. Pouco estudada nas escolas brasileiras, a trajetória de Dom Pedro I, que viria a se tornar Dom Pedro IV de Portugal, geralmente para em 1826, quando ele abdica do governo, deixa no pais seu filho de apenas 5 anos - o Pedro que se tornaria o sereno Dom Pedro II - e retorna a Portugal $[\ldots . .]^{123}$

\section{É importante observar como mesmo nos momentos em que tais} livros procuram se distanciar de uma história de ênfase biográfica, suas justificativas mostram-se tão tíbias quanto seus esforços para proceder de outro modo. 1808, por exemplo, abre com uma citação de um programa de divulgação histórica da BBC, de Londres ("As pessoas fazem a História, mas raramente se dão conta do que estão fazendo"124), e em suas primeiras páginas o autor já critica "a forma caricata com que o rei e a sua corte costumam ser tratados nos livros, no cinema, no teatro e na televisão", sendo que, em uma suposta contramão, o propósito do livro seria outro. ${ }^{125}$ Mas o que se lê nos subtítulos estampados nas capas seja de 1808 ("Como uma rainha louca, um príncipe medroso...") ou e 1822 ("Como um homem sábio, uma princesa triste e um escocês louco por dinheiro ajudaram $D$. 
Trata-se de pastiche da célebre assertiva de Karl Marx, cuja menção explícita por parte do autor de 1808 ou pressuporia uma informação que ele não possui, ou implicaria um componente inadequado dada a estratégia de marketing que sustentou a produção e circulação dessa obra. Em casos semelhantes, é recomendável que a obra apareça a seus leitores como a mais isenta e objetiva possivel, ou de orientação condizente com aquele que se espera seja o público preferencialmente consumidor dela.

\section{5}

"Resgatar a história da corte portuguesa no Brasil do relativo esquecimento a que foi confinada e tentar devolver seus protagonistas à dimensão mais correta possivel dos papéis que desempenharam...." GOMES, Laurentino. 1808: como uma rainha louca, um principe medroso e uma corte corrupta enganaram Napoleão e mudaram a História de Portugal e do Brasil. São Paulo: Planeta, 2007, p.21. 0 que esta pesquisa tem até aqui mostrado não encoraja tal noção de esquecimento, sequer a de um relativo.

\section{6}

Note-se a concepção de que o Brasil é obra de um indivíduo, ajudado por outros indivíduos. 0 argumento central de 1822 é o de que o Brasil "deu certo", isto é, "conseguiu manter a integridade do seu território e se firmar como nação independente" por uma mescla de "sorte, acaso, improvisação, e também de sabedoria de algumas lideranças". GOMES, Laurentino. 1822. Op. Cit., p.18

\section{7}

Gomes considera a Wikipédia exemplo de fontes de pesquisa "de extrema utilidade" e "não convencionais, ainda não reconhecidas pela historiografia oficial"; no entanto, acredita que "ao contrário dos livros e das fontes impressas tradicionais, essas fontes precisam ser consultadas com cautela". Idem, p.25. Nessa ideia que as fontes "tradicionais" dispensariam cautela reside uma característica desse livro, cujo autor parece crer em praticamente tudo o que lê, principalmente o que os historiadores chamariam de fontes primárias, no que se alinha com Priore, que em A carne e o sangue também evita qualquer tipo de crítica de fontes.

\section{8}

É notável como os dois capítulos de 1808 dedicados aos perfis individuais, respectivamente, de D. João e D. Carlota, não obstante realizarem um inventário de imagens depreciativas e caricatas construídas a respeito de ambos, não são capazes de superá-las, terminando simplesmente por reafirmá-las. GOMES, Laurentino. 1822. Op. Cit., cap.13 e 14.

129

Com o que reiteramos o diagnóstico de CARDOSO, Patrícia da Silva. Op. Cit., p.42.

130

NARLOCH, Leandro. Op. Cit., p.25 e p.178-179. Um leitor atento poderia se perguntar por que nem todo presidente vaidoso, cruel, louco e equivocado conduziu seu pais a uma guerra.
Pedro a criar o Brasil..." 126$)$, ou ainda em passagens como "a Wikipédia tem quase tudo a respeito dos personagens e acontecimentos relatados neste livro..." ${ }^{127}$ ) e muitas outras, ${ }^{128}$ logo se encarrega de desvanecer qualquer ilusão de uma história processual, de movimentos coletivos a darem sentido à ação não apenas dos personagens e grupos de sempre, mas também de outros que, não obstante serem cada vez mais esquadrinhados por historiadores, estão ausentes destes livros. ${ }^{129} 0$ autor do Guia politicamente incorreto, por seu turno, a despeito de constantemente evocar "uma nova historiografia [que] ganha força no Brasil", na qual teria se baseado para desmontar supostos mitos, é capaz de tentar convencer o leitor, por exemplo, de que a Guerra do Paraguai "aconteceu, sobretudo porque havia naquele país um presidente vaidoso, cruel, louco e equivocado", ${ }^{130}$ bem como que a "História do Brasil" a que o título da obra alude pode gravitar em torno de personagens cujas más condutas morais sua obra se empenha em apontar. ${ }^{131}$ Mesmo Del Priore, historiadora profissional, reconhecida por seus anteriores estudos acerca de uma história do cotidiano e de indivíduos "comuns", e cuja obra em questão é mais preocupada com uma história para além de indivíduos do que as acima mencionadas, afirma que "nenhuma mulher se negava a D. Pedro, não só por ser príncipe, mas por ser fogoso", ou que seu pai "nunca sorria". ${ }^{132}$ Naturalmente, mesmo o mais adesista dos leitores, capaz de acreditar em tais afirmações, ficará sem resposta à pergunta se Domitila "usaria os pelos púbicos em cachos ou se depilaria como faziam as cortesãs francesas". ${ }^{133}$

No caso de $O$ Chalaça, a recorrência à biografia de apelo histórico está no próprio cerne de composição da obra que, por ser mais livre do ponto de vista formal, e menos historicamente compromissada do que as demais, poderia partir de inúmeros pretextos oferecidos pela história do Brasil; não obstante, seu autor recorreu a alguns dos mais evidentes e convencionais. Não surpreende, assim, constatar que, um ano antes do filme Carlota Joaquina, o livro que seria umas inspirações para 0 Quinto dos Infernos leve adiante essa espécie de fixação coletiva pela suposta disenteria de D. Pedro às margens do Ipiranga, ${ }_{1}^{134}$ ou que ridicularize seu liberalismo político (que, aliás, tantos não especialistas custam a entender), já que quem mandou fechar a Assembleia e "sozinho" promulgou uma Constituição só poderia ser um tirano, um anti-herói. ${ }^{135}$

Essa ênfase no biográfico-anedótico demonstra uma curiosidade pela vida pessoal de personagens convencionais que emana dos autores e enreda seus leitores, todos a compartilharem uma espécie de voyeurismo público já caracterizado aqui como componente de um mercado cultural e de uma sociedade que the dão significado. Para todos os efeitos, contudo, é notável como a heroicidade e a exaltação encomiástica estão fora de moda (sem claro, desaparecerem por completo de outros suportes materiais, como já visto). Talentos, virtudes ou outros aspectos positivos, apenas quando forem improváveis, moralizadores ou - de preferência - amorosos e sexuais. ${ }^{136}$ Não é necessário muito esforço para entender a eficácia de tais perfis em uma sociedade que neles busca algo, ao mesmo tempo em que é impelida ao seu consumo.

Esse primeiro aspecto de tratamento da Independência resulta, também aqui, em interdições ao diálogo entre saberes acadêmicos e não acadêmicos. A exemplo do que já se observou em outras fontes, também nesses livros o conhecimento produzido pela academia, embora constantemente evocado, não é capaz de modificar versões arraigadas da Indepen- 
No que se releva o mesmo tipo de componente mercadológico que atende ao interesse do leitor pela vida privada das pessoas, quaisquer que elas sejam, em detrimento de visões complexas e matizadas de processos históricos. 0 mercado, contudo, não é isento, objetivo ou despolitizado. Daí o componente ideológico da afirmação de Narloch, a despeito de sua aparência contrária, de que "meu livro não é um estudo acadêmico. Ele é tão parcial quanto os estudos que eu critico. É um contraponto" (Entrevista a Monica Waldvogel... vídeo n.11). Ora, se todos os pontos de vista se equivalem, nenhuma crítica é possível, inclusive ao próprio Guia que, por seu turno, distribui fartamente suas criticas a quem (note-se bem: a quem, e a não a quê) seu autor bem entende.

132

PRIORE, Mary Del. A carne e o sangue. A Imperatriz D. Leopoldina, D. Pedro I e Domitila, a Marquesa de Santos. São Paulo: Editora Rocco, 2012. p.18 e 20. A exemplo de Priore (pp.17, 43, $152,205,208,228$ e 234 ) e de tantos outros antes deles, Narloch também está interessado nas virtudes e vicissitudes do órgão sexual de D. Pedro a ponto de a ele dedicar uma destacada página de seu livro. NARLOCH, Leandro. Op. Cit., p.280.

133

PRIORE, Mary Del. A carne e o sangue. Op. Cit., p.152.

134

TORERO, José Roberto. Op. Cit., p.108.

135

Idem, p.126-127. Essa versão relativamente livre do tema (dizemos relativamente, pois já se vê que quase nenhuma das versões aqui mencionadas é inteiramente original) encontraria eco, anos depois, na obra de um historiador profissional: VILLA, Marco Antonio. A história das constituições brasileiras: 200 anos de luta contra o arbitrio. São Paulo: Leya, 2011. Este autor, a exemplo de Torero, pretendeu depreciar a Constituição de 1824 por ser ela, supostamente, uma "colagem" de outras constituições da época; o que, de um ponto de vista minimamente sério da questão, não encontra nenhum fundamento (a resenha crítica de W. Steinmetz. 0 constitucionalismo brasileiro: narrativa da história do conflito entre liberdade e autoritarismo. Direitos Fundamentais \& Justiça, v. 6, p. 279-283, 2012, parece encerrar a questão). Teria Villa acreditado literalmente em livros como 0 Chalaça, ou sua postura apenas revela, mais uma vez, que nem profissionais da História estão isentos de influências (por mais amadoras que sejam) advindas de formulações não profissionais?

\section{6}

É possivel, então, que certas ênfases de uma das obras de Gomes (como a que atribui a D. Pedro uma "espantosa capacidade reprodutiva" por, sendo um homem de vinte e poucos anos, ter tido "três filhos em menos de um ano", "todos com mulheres diferentes", causem à maioria de seus leitores menos constrangimento do que o fazem a uma minoria deles. GOMES, Laurentino. 1822. Op. Cit., p.122.

137

TORER0, José Roberto. Op. Cit., p.111. dência. 0 texto de orelha de 0 Chalaça, "psicografado" por D. Pedro, assim como a apresentação do livro, no qual se lê uma paródia de discussões acadêmicas em torno da veracidade de seu conteúdo, indicam menos as pretensões à oferta de uma História amparada em obras de especialistas do que a recorrência a conteúdos historiográficos bastante tradicionais, como a ideia de que uma "nação brasileira" foi preparando a Independência, ou a de que as Cortes de Lisboa queriam recolonizar o Brasil; aqui, tais conteúdos mostram que o livro se ampara em saberes acadêmicos, porém não submetidos à crítica, o que torna a afirmação de que "é essa história que se conta até hoje no Brasil, e eu dou fé que é verdadeira"137 mais do que simples frase de efeito. Também 1808 e 1822 corroboram amplamente a ideia da Independência como uma luta nacional maniqueista entre brasileiros e portugueses (na qual as Cortes seriam, novamente, recolonizadoras ${ }^{138}$ ), mas buscam legitimação explícita em uma produção acadêmica que, segundo seu autor, referenda suas posições: 1808 começa com uma homenagem a uma historiadora profissional que 0 teria inspirado, ${ }^{139} 1822$ traz uma orelha com endossos acadêmicos ao livro, ${ }^{140}$ e ambos com frequência mencionam historiadores no corpo do texto, como, por exemplo, a "autora do melhor livro já escrito sobre a biblioteca [real portuguesa]".141 No entanto, aqui se vê algo muito semelhante ao que ocorre com livros didáticos, onde versões acadêmicas e não acadêmicas da História são aliadas apenas formais, incapazes de falar a mesma língua, resultando em muitas e severas incongruências de exposição. ${ }^{142}$ Aliás, embora 1822 traga muitas notas de final de capitulo, quase $20 \%$ delas ( 81 de 450 ) referem-se a apenas dois autores - Tobias Monteiro e Otávio Tarquínio de Sousa - cujas obras já tinham completado pelo menos meio século em 2010, o que deveria torná-las merecedoras de especial revisão. ${ }^{143}$

Embora A carne e o sangue proponha uma fórmula de difícil definição, mesclando biografia, romance e história, a resultar no que o autor de sua orelha considera "a abordagem mais original do período que vai da elevação do Brasil a Reino Unido [sic] às vésperas da Abdicação", é sabido tratar-se de algo nada novo. ${ }^{144}$ No quesito de diálogo com a academia, o mais original dentre esses livros é o Guia: embora, como já apontado, fale de "uma nova historiografia" da qual supostamente seu autor é porta-voz, seleciona com cuidado obras que possam corroborar suas próprias versões da história, não oferecendo ao leitor desavenças equivalentes. Como a pluralidade se dá somente em uma guerra declarada contra a versão "correta" (a do autor) e a versão "errada" (a de historiadores "nacionalistas" ou "comunistas"), o pensamento discordante serve basicamente ao escracho, o que ademais coaduna perfeitamente com as demandas de alguns nichos de mercado no Brasil. ${ }^{145}$ Não surpreende, pois, que seu tratamento da Independência insista no estereótipo da não-Independência, parcialmente referendado também por Gomes, mas tão criticado pela historiografia nas últimas décadas. ${ }^{146}$ Diferentemente deste, porém, cujo apelo mercadológico de suas obras não impede uma sincera tentativa de diálogo com a academia, a reivindicação de Narloch passa longe de tais intentos. ${ }^{147}$

É fácil constatar que o tratamento histórico dessas obras, tal qual aqui assinalado, não difere substancialmente dos encontrados em outras fontes, integrando-se de modo bastante adequado a um ciclo de noções, concepções e representações acerca da Independência a tipificar sua inserção em uma cultura de história no Brasil. Constata-se, também aqui, grande oferta de conteúdos a promoverem a subversão de fundamentos 
Nesse ponto, poucos anos depois as versões de história de Torero e Gomes ganhariam o reforço da de Narloch, (NARLOCH, Leandro. Op. Cit., p.284).

139

Maria Odila Dias, já mencionada anteriormente.

140

"Uma narrativa sensível e abrangente da história brasileira", segundo Elias Thomé Saliba; e "uma perspectiva ampla do período, sem deboche ou caricatura", de acordo com Jean Marcel Carvalho França. GOMES, Laurentino. 1822. Op. Cit., "orelha".

141

Trata-se de Lilia Moritz Schwarcz. Em 1808, 0 leitor não terá a informação de quantos ou quais outros livros já foram escritos sobre 0 assunto.

\section{2}

Um exemplo, dentre muitos: embora destaque "a contribuição decisiva de historiadores como Mary Karasch, Leila Mezan Algranti, Manolo Garcia Florentino e João Luís Ribeiro Fragoso", citandoos em vários momentos ao longo do livro, Gomes refere-se a "uma etapa na história europeia, conhecida como Velho Regime [sic], em que reis dominaram seus paises com mão de ferro e pode absoluto", a "brasileiros, habituados até então a ser tratados como simples colônia extrativista de Portugal", chama a "colônia" de "territórios dominados pelos portugueses" e afirma que em 1808 "o Brasil libertava-se de três séculos de monopólio português e se integrava ao sistema internacional de produção e comércio como uma nação autônoma" (GOMES, Laurentino. 1808. 0p. Cit., p.24, 32, 40, 102, 193, respectivamente). Tais afirmações são em muitos sentidos negadas por alguns dos mesmos historiadores mencionados.

\section{3}

1808 traz 690 citações ao fim dos capítulos, sendo 20\% (142 vezes) de autores como Pedro Calmon (18 vezes), Tobias Monteiro (38 vezes), Manuel de Oliveira Lima (45 vezes), Alexandre José de Melo Moraes (12 vezes), Joaquim Pedro de Oliveira Martins (18 vezes) e Francisco Adolfo de Varnhagen (11 vezes). Embora Gomes pretenda fazer uso de interpretações mais atualizadas sobre o tema, essa quantificação indica caracteristica marcante de 1808: a reedição de versões fortemente convencionais da história.

\section{4}

Palavras de Alberto Mussa (A carne e o sangue..., cit., "orelha"). Na década de 1940, Sérgio Buarque de Holanda já atacava a pretensão de hibridismo de biografias históricas romanceadas, nas quais "as qualidades próprias do romance e da biografia eram abolidas, em proveito de uma unidade superficial e suspeita", e procurava explicar seu consumo ampliado pela mediocridade de uma época marcada pela "ansiedade de encontrar refúgio e libertação em outras existências mais excitantes" (citado por GONÇALVES, Márcia de Almeida. Em terreno movediço: biografia e história na obra de Octávio Tarquínio de Sousa. Rio de Janeiro: EDUERJ, 2009, p.149-150).

145

Uma versão argentina da teoria do "complô historiográfico" encontra-se em obra bastante semelhante às até aqui analisadas: PIGNA, Felipe. temporais da história. Nesse quesito, 1808 e 1822 são igualmente fartos de erros factuais e anacronismos, ${ }_{1}^{148}$ ademais estimulados pela divisão do texto em capítulos curtos e autônomos - isto é, que se iniciam e terminam sem nenhuma conexão entre eles - que permitem uma leitura fracionada das obras $;{ }^{149}$ por imagens meramente ilustrativas: ${ }^{150}$ e pela inclusão de quadros cronológicos com informações erradas. ${ }^{151}$ As confusões temporais seguem também por passagens textuais, como as que se referem à Inglaterra e Holanda como lugares onde, no século XIX, supostamente "a realeza ia gradativamente perdendo espaço para os grupos representados no Parlamento", 152 quando em realidade isso ocorrera no século XVII; ao começo do século XIX como "tempo de pesadelos e sobressaltos para reis e rainhas", sendo que "dois deles enlouqueceram", 153 embora esses dois já tivessem "enlouquecido" no século XVIII; ${ }^{154}$ ou como "o período em que reis e rainhas eram perseguidos, destituidos, aprisionados, exilados, deportados ou mesmo executados em praça pública", 155 embora o último monarca executado o tenha sido em 1793; ou ainda as afirmações de que "a decisão [de transferir a Corte] já havia sido tomada e analisada diversas vezes por diferentes reis, ministros e conselheiros ao longo de quase três séculos", ${ }^{156}$ de que Portugal fora "soberano dos mares dois séculos antes", ${ }^{157}$ ou, finalmente, a de que "viajar [D. João] como hóspede do comandante britânico poderia soar politicamente incorreto".158 Para Del Priore, mesmo assim, 1808 "desvenda os acontecimentos com graça e leveza", sendo "uma síntese histórica que brilha pela limpidez das explicações [...], uma boa ideia sustentada por uma metodologia sem falhas". 159

A ideia de "politicamente incorreto", aliás, é de saída uma das mais contundentes contribuições do Guia para essa subversão dos fundamentos temporais da história, reforçada em suas páginas, por exemplo, com a mitificação do Brasil e do Chile como paraísos de estabilidade política em uma América Latina oitocentista convulsionada por "guerras civis, ditaduras e assassinatos em massa" que brotariam do México a uma "Argentina"160 tão inventada pelo autor como um fictício "vice reinado [sic] da Grande Colômbia".161 Também pela prioridade à pseudopolêmica a ensejar comparações anacrônicas, ${ }^{162}$ ou ainda uma interpretação da Independência como "um jogo de cartas marcadas" (porque segundo o livro "ninguém queria se separar de Portugal"163), tão maniqueísta quanto a de um Império do Brasil como uma espécie de personagem que, não obstante supostas "virtudes que são frequentemente esquecidas", necessitaria de uma defesa contra "acusações injustas" de que seria alvo. ${ }^{164}$ Assim, não é de surpreender se ao leitor do Guia escapar até mesmo uma simples informação, como a do Brasil ter sido o último ou o penúltimo país da América a abolir a escravidão. ${ }^{165}$

Ênfase anedótica em personagens convencionais, diálogos interditos ou puramente formais com conhecimentos especializados, assim como erros e anacronismos a promoverem uma destemporalização da História, não são características absolutas de todos os esforços por tratar da Independência para leitores interessados no passado e, nos dizeres de Gomes, não "habituados nem dispostos a decifrar a rebuscada linguagem acadêmica que [segundo ele] permeia toda a bibliografia sobre 1808 e seus desdobramentos". ${ }^{166}$ Há pelo menos duas frentes que oferecem alternativas a esse panorama, contribuindo para tornar ainda mais complexa a cultura de história no Brasil: livros a que se costuma chamar de paradidáticos, e magazines de História. Ambos recorrem a linguagens discursivas e visuais fáceis, contam com a colaboração ou são escritos por historiadores profis- 
Los mitos de la historia argentina. Buenos Aires: 2004. A ese respeito: RODRÍGUEZ, Martha. Los relatos exitosos sobre el pasado y su controversia. Ensayistas, historiadores y gran público, 20012006. In: DEVOTO, Fernando. (dir.). Op. Cit. p.117-137.

\section{6}

Narloch: "enquanto revolucionários e libertadores de boa parte do mundo travaram batalhas heroicas e conseguiam se livrar das garras das elites e dos paises colonialistas, por aqui não aconteceu nada, nada: ficamos sempre no quase". NARLOCH, Leandro. Op. Cit., p. 271-272 - aqui, o autor opta por, ao invés de tentar desmontar tal versão - e seguir o mesmo procedimento de quase todo o resto do livro - concluir que foi bom que as coisas tenham supostamente sido desse modo; saída pragmática face o desconhecimento que o autor tem da historiografia). Gomes: "o que se viu em 1822 foi, portanto, uma ruptura sob controle, ameaçada pelas divergências internas e pelo oceano de pobreza e marginalização criado por três séculos de escravidão e exploração colonial. Ao contrário dos Estados Unidos, onde a independência teve como motor a república e a luta pelos direitos civis e pela participação popular, no Brasil o sonho republicano estava restrito a algumas parcelas minoritárias da população" (GOMES, Laurentino. 1808. 0p. Cit., p.334 - aqui o leitor fica confuso em relação ao que se quis dizer, já que a escravidão negra foi mantida em boa parte dos Estados Unidos até 1865)

147

Enquanto Gomes tenta dialogar, Narloch quer apenas selecionar. A tônica politica do Guia novamente se revela: sua prioridade não é aquilo de que o livro trata, mas algo a que é possivel se chegar a partir disso.

148

Parte dos quais resulta de verdadeira obsessão por uma linguagem "simples". 0 mesmo ocorre no contexto argentino, com PIGNA, Felipe. Op. Cit.; e LANATA, Jorge. Argentinos: desde Pedro de Mendoza hasta la Argentina del Centenario. Buenos Aires: Ediciones B, 2002 (cf. a análise de RODRÍGUEZ, Martha. Op. Cit.)

149

Idêntica estratégia discursivo-mercadológica é utilizada, na Argentina, por Jorge Lanata. Cf. RODRíguEZ, Martha, Op. Cit.

150

Como vimos, fragmentação narrativa e imagens decorativas são recursos mercadológicos bastante utilizados também em livros didáticos e programas de televisão.

151

Como o das p. 86-87, onde se lê que "o mapa do Brasil mostra as fronteiras e divisas da época", não obstante apresentar delimitações então inexistentes, como as atuais dos estados do Maranhão, Piaui, Ceará e Rio Grande do Sul. Exemplos das tabelas: em 1816, "A Argentina declara sua independência da Espanha"; dois anos antes (em 1814?), "O México torna-se independente da Espanha" (GOMES, Laurentino. 1822. Op. Cit., p.8)

152

GOMES, Laurentino. 1808. Op. Cit., p.32-33. sionais, e circulam para além da academia; mas têm peso mercadológico muito inferior aos demais materiais até aqui analisados, bem como na própria cultura de história. 0 que não significa, porém, que os tratamentos dados à Independência por livros paradidáticos e magazines sejam imunes a caracteristicas que, marcantes nessa cultura, eles apenas tendem a evitar. Afinal, tais materiais, como todos os demais, também integram um ciclo de interações diretas e de compartilhamento de padrões.

Dois exemplos que muito reproduzem essas características: Viagem pela história do Brasil (1987), de Jorge Caldeira, ${ }^{167}$ e Brasil: Uma História (2010), de Eduardo Bueno. ${ }^{168}$ Ambos apresentam textos segmentados, farto manancial de imagens puramente ilustrativas e tão tradicionais e convencionais como a que imputa à Inconfidência Mineira o caráter de movimento preparatório à Independência do Brasil. ${ }^{169} 0$ livro de Bueno conta, ademais, com um prefácio de Mary Del Priore, a endossar as ênfases biográficas, caricatas e anedóticas da obra; ${ }^{170}$ suas palavras são, mais uma vez, sintomáticas de estratégias de legitimação de obras que buscam apoio no conhecimento acadêmico ao passo que tentam sobre eles afirmar uma superioridade fundada em sua capacidade para atingir - por estratégias mercadológicas bem definidas - a sociedade em geral:

\begin{abstract}
Independente das abordagens teóricas consagradas pelas academias, destacado da pesquisa histórica que se faz nas universidades, o autor identifica-se ao espirito de abertura e descoberta que domina nossa época. Exemplo de coerência intelectual, ele lê o Brasil numa chave jornalística onde fatos e personagens sublinham o peso do passado sobre condutas e decisões coletivas, assim como a permanência das decisões individuais sobre o curso da história. Menos preocupado em interpretar a significação das estruturas, ele extrai habilmente lições de fatos históricos. Em sua pena, a virtuosidade do vulgarizador, o charme do contador e a elegância do estilista combinam-se para oferecer ao leitor uma narrativa pouco convencional e repleta de biografias pitorescas, além de observações nada canônicas. ${ }^{171}$
\end{abstract}

Já outras obras de divulgação apresentam casos muito diferentes. A começar por outra da mesma Del Priore que, em parceria com outro historiador profissional, ${ }^{172}$ agora se apresenta como muito mais afeita a estruturas, coletividades e conhecimentos acadêmicos do que há pouco se mostrou; ${ }^{173}$ coloca-se, assim, em sintonia com vários livros paradidáticos específicos sobre a Independência, escritos também por historiadores profissionais e nos quais é dada ênfase a uma história processual, a uma diversidade de agentes sociais e de espaços político-geográficos, a diálogos verdadeiros com a academia, e a uma temporalização da história praticada de modo bastante natural. ${ }^{174}$ São vozes minoritárias e de menor impacto social, mas não são desprezíveis. Esse confronto entre forças coexistentes e desiguais ocorre também dentre obras voltadas, mais especificamente, ao público infanto-juvenil. ${ }^{175}$

Também em meio aos magazines, a Independência conhece tratamentos variados e potencialmente conflitivos. No geral, as cinco publicações aqui analisadas (Aventuras na História, História Viva, Leituras da História, Nossa História e Revista de História da Biblioteca Nacional) apresentam grande flexibilidade em termos da natureza de seus textos, a incluirem reportagens, notícias, artigos de opinião, análises, entrevistas, propostas de atividades e pequenas notas, envolvendo desde especialistas acadêmicos até leitores leigos. Todos empregam linguagens fáceis, sendo que com frequência os textos são revisados e ou mesmo reescritos 
Aliás, D. Maria I foi considerada impedida e 0 governo passou a D. João em 1792, e não em 1799, como afirma o livro.

155

GOMES, Laurentino. 1808. Op. Cit., p.39.

156

Ibidem, p.48. Teria sido intenção do autor falar de quase dois séculos ao invés de três? Mesmo assim, teria sido tal decisão tomada desde o século XVII?

157

Ibidem, p.55. "Soberano" em começos do século XVII, quando seu império estava incorporado à monarquia espanhola? Teria sido intenção do autor falar em três séculos antes? Mesmo assim, alguém poderia sustentar seriamente tal ideia?

158

Ibidem, p.89. Outros exemplos: a afirmação de que, em 1807, "o imperador francês era o senhor absoluto da Europa", não obstante não ter conquistado Portugal, Grã-Bretanha e Rússia, sendo que mais adiante, em 1801, estaria toda "Europa ocupada por Napoleão Bonaparte" (p.34 e 47); a presunção de estímulos às guerras napoleônicas na capacidade transformadora de uma Revolução Industrial (p.43), mas que antes das guerras mal tinha começado na Inglaterra (menos ainda alhures); a concepção de um Portugal que "no começo do século XIX [...] tinha uma total dependência em relação Brasil" (p.46), sendo que "o ouro, o fumo e a cana de açúcar produzidos na colônia constituiam o eixo de suas relações comerciais", embora se saiba que Portugal não era totalmente dependente do Brasil, menos ainda de um ouro cuja produção há muito já entrara em decadência; a afirmação de que "a dependência [de Portugal em relação ao Brasil] tinha crescido gradativamente desde que Vasco da Gama havia aberto o caminho para as Índias e Pedro Álvares Cabral aportado com sua esquadra na Bahia" (p.46), como se Portugal sempre tivesse dependido do Brasil desde então; ou, finalmente, as afirmações de que o reformismo português acabou em 1777, com a queda de Pombal, (p.61), e de que o Correio Braziliense virou "o primeiro jornal brasileiro criado pelo jornalista gaúcho Hipólito José da Costa" (p.71)

159

PRIORE, Mary Del. 0 ano que definiu o Brasil. Veja, 12/09/2007. Cit. por CARDOSO, Patrícia da Silva. Op. Cit., p. 42-43.

160

Gomes a enxerga já no século XVIII. GOMES, Laurentino. 1808. Op. Cit., p.47.

161

NARLOCH, Leandro. Op. Cit., p.272.

162

"Desse ponto de vista, a monarquia teve para o século XIX o mesmo papel da ditadura militar no século XX: evitar que baixarias ideológicas instaurassem o caos entre os cidadãos". Idem, p.274. Anacronismo comparável às afirmações, do mesmo autor, de que as populações indigenas por editores, diagramados em formatos atraentes e em meio a imagens que poucas vezes são analisadas, em geral servindo de mera ilustração. No entanto, nesse conjunto percebe-se uma clivagem: os conteúdos de História Viva, Nossa História e Revista de História da Biblioteca Nacional tendem a ser mais ávidos e eficientes no diálogo com a academia do que os presentes em Aventuras na História e Leituras da História. Outra caracteristica comum a todos, amplamente presente também em outras fontes, como vimos, é sua inclinação a um teor revisionista, a oferecer, em primeiro lugar, uma ou várias versões supostamente tradicionais e prontas do tema, logo uma supostamente nova visão a desmontá-la. Tal promessa, evidentemente, não garante sua realização. ${ }^{176}$

Mesmo assim, é possivel considerar os magazines o suporte material mais inovador e dissonante no tocante a noções, concepções e representações acerca da Independência atuantes em uma cultura de história no Brasil. Por um lado, provavelmente isso se dê pelo fato de serem eles constante e intensamente visitados por acadêmicos empenhados, ou no mínimo interessados, na divulgação não acadêmica de seus saberes sobre a história; por outro, por traduzirem mais intensamente do que outras fontes, os interesses de uma sociedade em torno da história, mas com peso mercadológico menor do que, por exemplo, livros didáticos, programas televisivos ou livros concebidos, desde o seu nascedouro, para serem best-sellers. Qual seu grau de autonomia em relação a um universo de referências por eles compartilhadas? Qual o peso de sua atuação na cultura de história? Qual o seu potencial de modificar essa cultura, e quais os limites a eles impostos? Por fim: caso tal diagnóstico seja mesmo pertinente, têm os magazines condições ou interesse de fazer jus ao que poderia ser a eles imputado como uma espécie de vocação, sendo eles mesmos bastante variados ou, em muitos sentidos, até mesmo antagônicos?

\section{8 - Convergências e conclusões}

Após tudo o que foi observado, deve-se, afinal, retomar a pergunta inicial desta pesquisa: como os brasileiros vêm a Independência do Brasil? E no esteio de uma resposta possivel, plasmada pela observação de uma cultura de história, retomar a reflexão acerca de como a Independência é vista, no Brasil, por seus historiadores.

A depreender das fontes aqui analisadas, com suas limitações, mas também com sua abrangência e variedade, pode-se dizer que no Brasil, atualmente, a Independência é tema bastante presente e atuante na sociedade; e ainda que essa sociedade nem sempre manifeste interesse por ele ou por história em geral, ela se mostra motivada e capaz de desenvolver noções de história que, por seu turno e com regularidade, ensejam concepções e representações variadas, coexistentes e conflitivas. Dada a variedade e o impacto social dessas fontes - principalmente os livros didáticos e os materiais audiovisuais - é possivel agora afirmar, de modo conclusivo, que a Independência "paira" por sobre uma sociedade que não necessariamente se posiciona a seu respeito de modo consciente, claro e coerente, que muitas vezes mesmo deprecia e ridiculariza seu passado coletivo, mas que não deve ser considerada completamente indiferente à História, como muitas vezes costuma-se dizer.

Parece evidente que os detratores da Independência são mais numerosos e por vezes mais virulentos do que seus defensores que, não obstante, estão longe de serem irrelevantes. Em meio a essa parcial dicotomia, 
da América, como segundo ele detestariam viver na mata cheia de mosquitos, teriam passado a derrubá-la com gosto quando os primeiros portugueses quiseram pau-brasil; ou a de que aos mesmos nativos os leitores do Guia deveriam agradecer pelo hábito contemporâneo de fumar "ervas deliciosas". Idem, p. 28 e segs.

163

Ibidem, p. 281.

164

Ibidem, p. 275.

165

Afirma que "o Brasil foi o penúltimo país da América a abolir a escravidão"; mas logo em seguida, que "pouco depois de Cuba, foi o último pais da América a libertar os escravos". Ibidem, p. 285.

166

Ibidem, p. 22. Se toda a bibliografia a que ele se refere fosse assim, não poderiamos prosseguir na análise de nossas fontes.

167

CALDEIRA, Jorge. Viagem pela história do

Brasil. São Paulo: Companhia das Letras, 1997. Acompanhado de um CD-Rom. Quando de seu lançamento, contou com amplo suporte midiático a conferir-Ihe um destaque via de regra positivo; pouco depois, no programa Roda Viva, da TV Cultura de São Paulo, seu autor recebeu duras críticas dos historiadores profissionais John Manuel Monteiro e José Jobson Arruda.

168

BUENO, Eduardo. Brasil: uma história. São Paulo: Leya, 2010 (mesma editora do Guia politicamente incorreto e do livro de M. A. Villa acima mencionado, História das constituições brasileiras). A obra é uma reedição atualizada de Brasil: uma História: a incrivel saga de um país (São Paulo: Ática, 2003).

169

Segundo Caldeira, "nas Minas Gerais, apesar das proibições, havia algum tempo circulavam os livros que Portugal tentava proibir. Muitos membros da elite local procuravam interpretar o momento segundo as novas ideias de liberdade. $\mathrm{E}_{1}$ em vez de protestar contra Portugal, passaram a pensar na independência do Brasil"; assim, "a semente estava lançada: a ruptura com Portugal tornou-se a ideia central de muitos brasileiros" (CALDEIRA, Jorge. Op. Cit., p.112 e segs.). Bueno, por seu turno, afirma: "embora a historiografia oficial considere a Conjuração uma luta pela liberdade no Brasil, para o historiador norte-americano Kenneth Maxwell, autor de a devassa da devassa, o melhor livro, sobre o tema, 'a conspiração dos mineiros era, basicamente um movimento de oligarcas, no interesse da oligarquia, sendo o nome do povo invocado apenas como justificativa'". (BUENO, Eduardo. Op. Cit., p.141). Embora logo atrás tenha dito que "José de Maia e Barbalho, entrou em contato com Thomas Jefferson, então embaixador dos EUA na França, sondando-o sobre um possivel apoio à independência do Brasil" (Idem, p. 141 e 138). Caldeira vê ainda as Cortes de Lisboa e a Independência segundo os clássicos vieses, respectivamente, de "recolonizadoras" e de conflito entre "brasileiros" e "portugueses" (CALDEIRA, Jorge. Op. Cit., p.142). muitos denominadores comuns aproximam o que não parece ser, jamais, uma disputa de cunho partidário, pois ela é incapaz de engendrar ações pragmáticas e sectárias seja "contra" ou "a favor" da Independência. Em primeiro lugar, porque ambas as posições são capazes de convergirem, por exemplo, em termos de valorização de datas e personagens; de um reconhecimento da validade de saberes acadêmicos (independentemente de dialogarem com eles ou de nutrirem posições críticas a seu respeito); de embaralharem referências temporais; e de se renderem com facilidade às demandas de um mercado educacional e cultural não só de bens materiais, mas também de capitais simbólicos, no qual a vulgarização de vidas privadas alheias, o presuntivo combate a "histórias oficiais" reais ou imaginárias, ou a ostentação de posições sobre a história podem perfeitamente interagir e se assemelhar. Para todos os efeitos, porém, o mais importante é que tanto 0 ataque quanto a defesa da Independência demonstram atitudes em relação à história, permeadas por um número certamente mais numeroso de agentes que mesclam vários componentes de uma e de outra posição, e que fazem com que a cultura de história que a todos envolve seja multifacetada, menos dicotômica e mais complexa do que a noção excessivamente ambígua de "interesse do brasileiro pela história" permitiria entender.

A Independência é um dos componentes dessa cultura; certamente, um componente central e dos mais facilmente identificáveis como capazes de revelar atitudes perante a história que, conforme estabelecido já no início dessa pesquisa, não devem negligenciar o que, numa primeira abordagem, poderia parecer ausência de consciência ou de interesse pelo passado. Mas não é o único componente, sequer um dos únicos importantes. Mantendo-se a coerência da abordagem conferida até aqui ao fenômeno, em uma cultura de história o mais e o menos importante são, paradoxalmente, igualmente importantes. Pois as atitudes de uma sociedade perante a história, dentre as quais suas recusas e interdições, jamais se resumirão a um recorte temático específico que pode até funcionar razoavelmente para os historiadores acadêmicos, mas que não faria sentido a representantes, reprodutores e criadores não acadêmicos de conhecimento histórico.

A análise aqui realizada, e que muito ganharia com a extensão sociogeográfica de seu espaço de observação, principalmente da sondagem de opinião, parece deixar fora de dúvida que a maioria das fontes portadoras de noções, concepções e representações acerca da Independência no âmbito não acadêmico são, basicamente, recriadoras de conteúdos fortemente convencionais, pouco ou nada inovadores em relação ao que se poderia encontrar em outros contextos sociais brasileiros anteriores que pudessem igualmente ser submetidos a uma investigação como a que foi aqui realizada. Atualmente, observa-se uma enorme massa de elementos reiterativos, parcialmente reconfigurados em função de demandas sociais e mercadológicas típicas do nosso tempo, e na qual o destoante é, sem dúvida, exceção. Conclui-se, então, que tais suportes traduzem atitudes da sociedade brasileira perante a Independência e a história; simultaneamente, reproduzem tais atitudes e reforçam um ciclo tanto mais eficiente em função de um conjunto de características dessa sociedade em termos de perfis culturais, educacionais e econômicos que aqui puderam ser referidos apenas genericamente.

Seguramente, em qualquer cultura de história, eventos coletivamente traumáticos não poderiam ser submetidos a uma lógica de desmonte e 
Como os efeitos da disenteria de D. Pedro, que pouco depois o mesmo Bueno reexaminaria em sua série televisiva É muita história, já aqui analisada. Curioso como Bueno evoca, constantemente, uma "história tradicional" da qual não apenas não se vê como representante, mas como dela combatente (estilo argumentativo que, como vimos, pouco depois seria reeditado, agora por Narloch e seu Guia). De acordo com as precisas palavras de José Cândido de Oliveira Martins, a partir de uma ideia de E. Wesseling, "o alvo principal do discurso irônico é a história canônica, o repositório de fatos estabelecidos e as interpretações daqueles fatos, mas também os textos do passado da memória cultural, maltratados por um uso contrário ao tradicional". Cf. MARTINS, J. C. de Oliveira. Portugal e Brasil de D. João VI na meta-ficção historiográfica de autores portugueses contemporâneos. In: OLIVEIRA, P. M. (Org.) Op. Cit., p.104.

171

PRIORE, Mary Del. Prefácio. In: BUENO, Eduardo. Op. Cit., p.5.

172

PRIORE, Mary Del; VENÂNCIO, Renato Pinto. Uma breve história do Brasil. São Paulo: Planeta do Brasil, 2010. Este livro é uma edição revisada e atualizada de 0 livro de ouro da História do Brasil dos mesmos autores, publicado no Rio de Janeiro pela Ediouro em 2001. 0 texto sofreu pequenos ajustes de uma edição à outra.

173

Agora desautorizando (dentre outros) Bueno, afirmam os autores a respeito de D. João: "Com justiça, nada se encontrava de burlesco neste personagem" (Uma breve história..., op. cit. p.159-160). Tal postura, algo esquizofrênica, tem antecedentes ilustres em outras historiografias. Na década de 1950, Oliveira Martins, por exemplo, caracterizaria criticamente o "povo português" como "caso, talvez único na Europa", por não possuir "alma social" e supostamente se comprazer "em escarnecer de si próprio, com os nomes mais ridículos e o desdém mais burlesco"; e isso não obstante o próprio autor ter tratado de D. João como uma "sombra espessa de uma série de reis doidos ou ineptamente maus", "velho, pesado, sujo, gorduroso, feio e obeso" (MARTINS, Oliveira. História de Portugal. Lisboa: Guimarães, 1951, t.2, p.325 e 286-287, respectivamente; Cit. por CARDOSO, Patricia da Silva. Op. Cit., p. 39.

\section{4}

Dentre outros: ALGRANTI, Leila Mezan. D. João VI e os bastidores da independência. São Paulo: Ática, 1986; MATTOS, Ilmar Rohloff de; ALBUQUERQUE, Luis Affonso S. de. Independência ou morte: a emancipação politica do Brasil. São Paulo: Atual, 1991; OLIVEIRA, Cecilia Helena. A independência e a construção do Império 1750-1824. 2a ed. São Paulo: Atual, 1995; BERBEL, Márcia. A independência do Brasil (18081828). São Paulo: Saraiva, 1999; LYRA, Maria de Lourdes Vianna. 0 império em construção: Primeiro Reinado e Regências. São Paulo: Atual, 2000; SLEMIAN, Andréa; PIMENTA, João Paulo. O nascimento político do Brasil. Rio de Janeiro: DPCA, 2003; OLIVEIRA, Cecilia Helena. 7 de setembro de 1822: a independência do Brasil. São Paulo: Companhia Editora Nacional, 2005; detração como no Brasil ocorre, em parte, com a Independência. Além disso, a ordem de prioridades das atitudes sociais perante a história muda constantemente, alterando essa cultura, abrindo inclusive a possibilidade de inversão de disputas em torno de temas ou mesmo de transformação de estatuto de um tema que, por exemplo, pode deixar de ser traumático e, assim, se submeter à sátira; ou que de pouco relevante, pode ser elevado à condição de componente identitário dessa sociedade. Porém, estes são processos raros e lentos, na medida em que as próprias sociedades do mundo atual que podem se submeter a investigações em torno de suas culturas de história possuem mecanismos de autorreprodução e de auto-perpetuação enraizados.

Por tudo isso, e restringindo novamente o escopo dessas conclusões, aos historiadores da Independência parece não convir que se considerem alheios a essa cultura de história, ao seu funcionamento e às implicações da mesma para seu próprio trabalho. Embora ajam de modos autônomos, vinculados a escolhas pessoais fundadas em diagnósticos, necessidades e idiossincrasias acadêmicas, também os historiadores carregam consigo 0 peso de formações escolares e sociais mais amplas (de acordo com uma cultura de história que os envolveu desde cedo), pensam segundo tradições que não se restringem ao mundo acadêmico, e atuam em uma sociedade cujas demandas e determinações mercadológicas se fazem presentes de modo cada vez mais intenso também nas universidades, nos centros de investigação e nas agências de fomento à pesquisa. ${ }^{177}$ Tudo isso poderá ajudar a explicar porque profissionais da História tardam tanto a reverem determinadas posições acerca de seus temas de estudo, porque são capazes de reproduzir tão facilmente "verdades" anteriormente estabelecidas, e porque são cada vez mais treinados, desde os estágios iniciais de sua formação, a rejeitarem o exercício da crítica aberta e honesta, bem como o diálogo transversal e o trabalho coletivo. Não parece incrivel, por exemplo, que após tudo o que a historiografia acadêmica produziu acerca da Independência do Brasil, tanta gente ainda a trate como um conflito maniqueísta de interesses nacionais entre brasileiros e portugueses, ou como um processo de simples reacomodação de interesses elitistas em prol da manutenção da ordem, ou, finalmente, como uma miriade de vontades individuais a moverem a história? Estas não são "verdades" apenas dos não especialistas em História: também muitos profissionais da matéria ainda parecem dispostos a sustentá-las.

0 diagnóstico de tal situação não significa, entretanto, a defesa de que a História da Independência seja reescrita em medida mais intensa do que, naturalmente, já o é todo e qualquer tema, toda e qualquer história. Na escrita da História, assim como em qualquer outro ramo das ciências humanas, o mais novo não é, necessariamente, o mais esclarecedor; há uma dimensão parcialmente cumulativa do conhecimento histórico, mas também há a possibilidade do estabelecimento de certos consensos duradouros, a persistirem não por simples inércia, mas por reiteração dinâmica e crítica de paradigmas devidamente revistos. 0 que não pode ser ignorado, contudo, é a necessidade de uma cuidadosa apreciação, por parte do especialista de uma matéria, do fato de que determinados pressupostos da mesma podem ter sido estabelecidos anteriormente, e que seu trabalho esteja condicionado por uma cultura de história cujo diagnóstico pretérito implica não apenas uma valorização de conhecimentos veiculados por sua sociedade, mas também formas de atuação qualificada nessa mesma sociedade. 
SLEMIAN, Andréa; PIMENTA, João Paulo. A Corte e o Mundo: uma história do ano em que a família real chegou. São Paulo: Alameda, 2008.

\section{5}

De um lado, livros como: BAGNO, Marcos. 0 processo de independência do Brasil: adaptado do livro "Diário de uma viagem ao Brasil", de Maria Graham. São Paulo: Ática, 2003 (consultoria histórica: Tania Regina de Lucca); PEREIRA, André. A independência do Brasil: documentos e atividades. Ao Livro Técnico, 1999 (Ilustrações: Tibúrcio); e o mais afinado com a academia: LUSTOSA, Isabel. A história do Brasil explicada aos meus filhos. Agir, 2007. De outro, as adaptações de GOMES, Laurentino; ORTIZ, Denise. 1808 - edição juvenil. São Paulo: Planeta, 2008 (ilustrações Rita B. Brugger); e GOMES, Laurentino. 1822 - edição juvenil. São Paulo: Nova Fronteira, 2011 (ilustrações Rita B. Brugger).

\section{6}

Foram analisados 185 artigos. De 226 menções a 20 temas relativos à Independência identificados, 74 dizem respeito a oito temas correspondentes a personagens convencionais, como D. Pedro, D. João, Carlota, Bonifácio, Leopoldina, Domitila, Amélia e Tiradentes. Em termos de chamadas e conteúdos, por exemplo, a Aventuras na História n. 37 traz na capa a chamada "A nova face de D Pedro I. Tudo o que a escola não contou sobre o herói da independência que se tornou símbolo de liberdade na Europa do século XIX" (guiadoestudante.abril.com.br/aventuras-historia/ independencia-ou-nada-434846.shtml, acesso em 02/04/2014). Outros artigos pretendem revisar até mesmo de interpretações recorrentes na academia (revistadehistoria.com.br/secao/livros/ a-independencia-brasileira-novas-dimensoes, acesso em 02/04/2014). Já a Nossa História n.11 explicita esse interesse das revistas em identificar e criticar imaginários acerca da Independência.

\section{7}

0 que não significa que historiadores e demais cientistas sociais sejam constante e plenamente avaliados. Como bem se sabe, tais profissionais são avaliados apenas em alguns quesitos de sua atuação, jamais em todos.

\section{8}

Interessantes propostas a respeito encontramse em: MEGLIO, Gabriel Di. Wolf, el lobo. Observaciones y propuestas sobre la relación entre producción académica y divulgación histórica. Nuevo Topo. Revista de historia y pensamiento crítico, n. 8, 2011, p.107-120. Infelizmente, não pudemos dialogar com as propostas de outro autor, publicadas quando nosso próprio artigo estava praticamente concluido: MALERBA, Jurandir. Acadêmicos na berlinda ou como cada um escreve a História? uma reflexão sobre o embate entre historiadores acadêmicos e não acadêmicos no Brasil à luz dos debates sobre 'Public History.' História da historiografia n. 15, ago./2014, p.27-50.
É frequente a acusação, dirigida aos historiadores, de manterem-se presos a linguagens herméticas, a conhecimentos hiper-especializados e a diálogos corporativos muito limitados. Dentre aqueles historiadores que se incomodam com vários aspectos da realidade mostrada por esta investigação, costumam-se, então, responsabilizar a si mesmos, enquanto grupo profissional, pela proliferação de maus suportes de divulgação histórica, já que eles próprios pouco se apresentariam como capazes de fazer algo melhor do que outros agentes sociais que não só representam, mas principalmente recriam (de modo tímido) conteúdos de História. Essa autocrítica é necessária e salutar. ${ }^{178}$ No entanto, há que se considerar três coisas. Primeiro: um grande número de historiadores acadêmicos há muito e de muitas maneiras já trabalha nessa direção. Segundo: tal trabalho impõe uma capacidade de atuação em sistemas não só educacionais, mas também editoriais e midiáticos, fortemente capitalistas, viciados e cheios de nuances, o que por vezes implica o manejo de ferramentas tão específicas e complicadas para os historiadores quanto o são algumas das ferramentas destes para o restante da sociedade. Terceiro: dialogar com a sociedade na condição de especialistas também impõe aos historiadores problemas a se ter em conta. Inclusive porque se, no caso da História da Independência, vimos que o trabalho de não acadêmicos não tem se mostrado dos mais inspiradores, a chancela do especialista não é garantia de uma divulgação consistente. Como e para que divulgar conhecimento histórico em uma sociedade que já possui numerosas formas de pensar e de representar a história? Há muitas respostas possiveis a essa pergunta. Quase todas, poderiam perfeitamente substituir a ideia de divulgação pelas de diagnóstico e diálogo. Diagnóstico de uma cultura de história, base para um diálogo com a própria sociedade. 